University of Nebraska - Lincoln

DigitalCommons@University of Nebraska - Lincoln

USDA National Wildlife Research Center - Staff Publications
U.S. Department of Agriculture: Animal and Plant Health Inspection Service

April 1999

\title{
An Overview of the Biology of the Brown Treesnake* (Boiga irregularis), a Costly Introduced Pest on Pacific Islands
}

Gordon H. Rodda

Thomas H. Fritts

Michael J. McCoid

Earl W. Campbell III

Follow this and additional works at: https://digitalcommons.unl.edu/icwdm_usdanwrc

Part of the Environmental Sciences Commons

Rodda, Gordon H.; Fritts, Thomas H.; McCoid, Michael J.; and Campbell, Earl W. III, "An Overview of the Biology of the Brown Treesnake* (Boiga irregularis), a Costly Introduced Pest on Pacific Islands" (1999). USDA National Wildlife Research Center - Staff Publications. 659.

https://digitalcommons.unl.edu/icwdm_usdanwrc/659

This Article is brought to you for free and open access by the U.S. Department of Agriculture: Animal and Plant Health Inspection Service at DigitalCommons@University of Nebraska - Lincoln. It has been accepted for inclusion in USDA National Wildlife Research Center - Staff Publications by an authorized administrator of DigitalCommons@University of Nebraska - Lincoln. 


\title{
2 An Overview of the Biology of the Brown Treesnake* (Boiga irregularis), a Costly Introduced Pest on Pacific Islands
}

\author{
Gordon H. RODdA \\ Thomas H. Fritts \\ MichaEL J. MCCoID \\ Earl W. Campbell III
}

\section{THE GENUS BOIGA}

The 20-30 species of the genus Boiga (Colubridae, Boiginae) range from tropical Africa through southern Asia to Melanesia and Australia (Leviton, 1968). Collectively, they are known as catsnakes, mangrove snakes, or treesnakes (Obst et al., 1988; Greene, 1989). The common name "catsnakes" is sometimes used for snakes in the genus Telescopus as well (Obst et al., 1988).

Members of the genus Boiga are nocturnal, oviparous, opisthoglyphic, euryphagic, and slender; they have vertical elliptical pupils (thus "cat" snakes) set in large eyes, and short, blunt heads that are noticeably larger than their necks. With one exception they are arboreal or semiarboreal (Obst et al., 1988), but they are found on the ground more frequently than some other arboreal snakes. Most inhabit forested areas, although the one terrestrial species, Boiga trigonata, ranges into the steppes of central Asia (Obst et al., 1988).

Little is known about the catsnakes. Not much has been published about most species other than basic descriptions (Leviton, 1968) and scattered natural history notes (Woodward, 1960; Jones, 1961; Rosevear, 1965). Boiga dendrophila is sold commonly as a pet and zoo animal; its venom and habits have been studied, as have those of several other species (especially B. cyanea and B. blandingi), mostly in captivity (Barach, 1952; F. Groves, 1973; J. D. Groves, 1974; Burger, 1975; Sakai et al., 1984; R. D. Howard, 1984; C. J. Howard, 1987; Minton and Dunson, 1978). The gut contents of Boiga museum specimens were tabulated by Greene (1989) and Shine (1991). Intensive field studies of snakes of the genus Boiga have been conducted only on $B$. irregularis ( $>100$ papers).

* We follow H. W. Greene, Snakes: The Evolution of Mystery in Nature (University of California Press, 1997), in using single words for common groups of snakes such as treesnakes and rattlesnakes.

44

RODDA, G. H., T. H. FRITTS, M. J. MCCOID, and E. W. CAMPBELL III. 1999. An overview of the biology of the Brown Treesnake (Boiga irregularis), a costly introduced pest on Pacific Islands. Pages 44-80 in Rodda, Gordon H., Sawai, Yoshio, Chiszar, David, and Tanaka, Hiroshi, editors. Problem snake management : the habu and the brown treesnake . Cornell University Press, Ithaca, NY. 534p. 


\section{THE SPECIES}

Boiga irregularis is the easternmost and southernmost Boiga, and it appears to have spread southward and eastward fairly recently in evolutionary time (Shine, 1991). Its range excludes the Lesser Sundas but includes the Moluccas and extends from Wallace's line west of Sulawesi through New Guinea and the humid northern and eastern rims of Australia to the Santa Cruz Islands (Solomon Islands, but not known from San Cristobal; Fig. 2.1).

The Brown Treesnake is the most abundant arboreal snake in many parts of its range in Australia, probably because there are few nocturnal arboreal competitors (Shine, 1991). The nominal species $B$. irregularis includes a wide variety of color morphs; markings range from vague to distinct dark blotches on a background of brown to yellow through blue-and-white or red-and-white banding in parts of Australia (Cogger, 1992). Although the coloration of B. irregularis varies across the snake's range, coloration and scutellation are relatively constant at individual localities (Rodda et al., 1992). Boiga flavescens, a Boiga described from

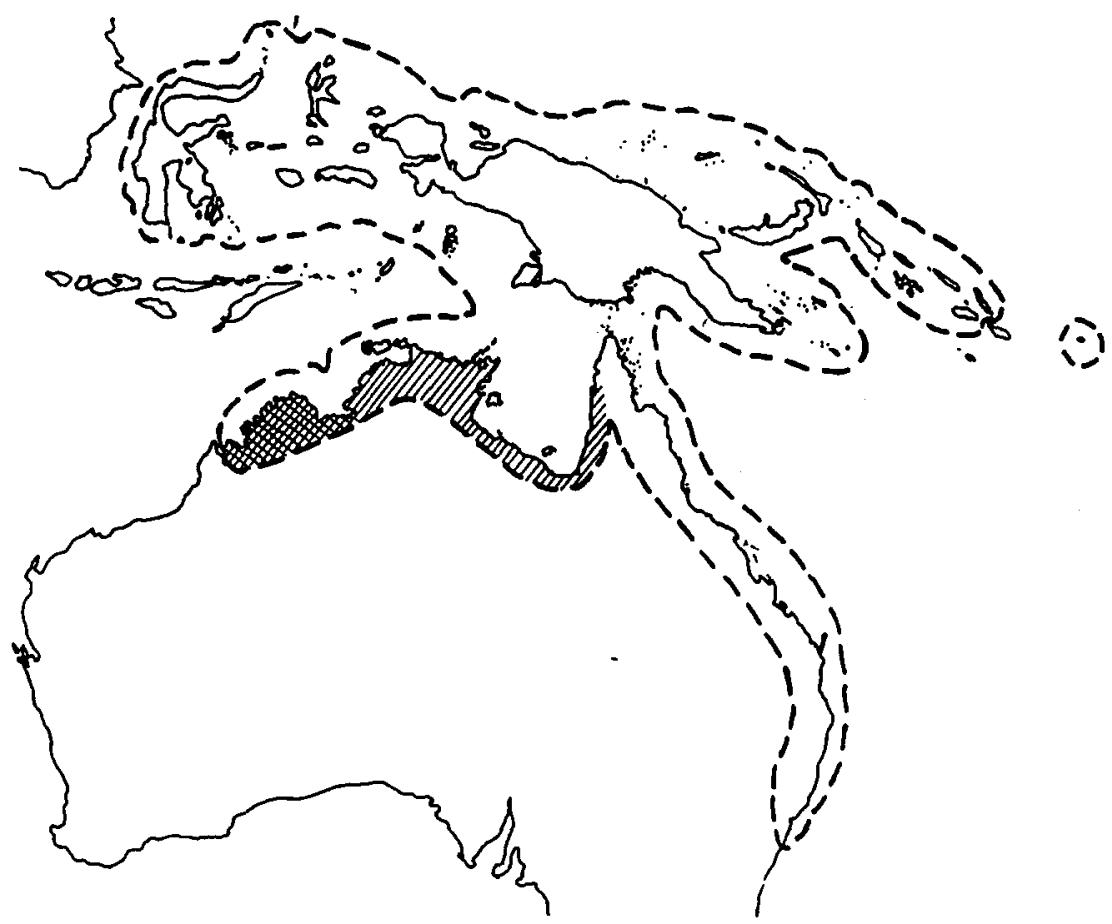

Figure 2.1 Range of the Boiga irregularis complex. Crosshatched areas of northern Australia are sometimes treated as being inhabited by $B$. fusca ornata, the right-hatched areas by B. f. fusca (Ehmann, 1992). 
Sulawesi by Duméril and Bibron (in Duméril et al., 1854), is considered by modern authors (e.g., Bosch, 1985) to be a variant of $B$. irregularis.

\section{How Many Species of Boiga Occur in Australia?}

Worrell (1963), Gow (1976), Greene (1989), Shine (1991), and Cogger (1992) recognized only one species of Boiga in Australia: B. irregularis. Kinghorn (1964), Storr et al. (1986), and Ehmann (1992) divided the Australian forms into twospecies: $B$. fusca and $B$. irregularis. The two are believed to be parapatric. With the exception of Kinghorn, however, those arguing for two species have not specified how the two are to be distinguished (Storr et al., 1986; Ehmann, 1992), and there is disagreement among the three proponents of the two-species concept regarding which species is found outside Australia and the distributional limits within Australia. Boulenger (1896) and Kinghorn (1964) specified that $B$. fusca could be distinguished from $B$. irregularis on the basis of the relative size of the anterior palatine teeth (subequal to posterior palatine teeth in $B$. fusca, enlarged in $B$. irregularis). Kinghorn additionally distinguished the two species in Australia on the basis of contact between the preocular and frontal head shields (separated in $B$. fusca; touching in $B$. irregularis). Contact between these scales is variable in $B$. irregularis outside Australia (see below). Kinghorn classified the form ranging from Western Australia to New South Wales as B. fusca, and the form found near Cape York at the northern tip of Queensland as B. irregularis. Even though Storr et al. did not define $B$. irregularis or characterize its distribution, they divided $B$. fusca into two subspecies: B. f. ornata in Western Australia and nearby parts of Northern Territory; and B. f. fusca in northern Northern Territory, north and east Queensland, and New South Wales. Ehmann agreed with Storr et al. in describing the range of $B$. f. ornata, but identified the range of $B$. f. fusca as being northern Northern Territory, northwestern Queensland, and probably New Guinea. Ehmann considered the form occurring from Cape York to New South Wales to be $B$. irregularis. The various taxonomic rearrangements that have been suggested by the Australians and others are complicated by the lack of the type specimen of $B$. irregularis and the absence of a type locality (Welch, 1988). A modern taxonomic review is needed.

Ehmann called B. fusca the Northern Brown Treesnake (although it is found farther south than are most other "Brown Treesnakes"); this form is also known as the Banded Catsnake (Storr et al., 1986) and the Doll's Eye or Brown Treesnake (Kinghorn, 1964). In addition to being called the Brown Treesnake, B. irregularis is known as the Eastern Brown Treesnake (Ehmann, 1992), Red-banded Treesnake, Pandanus Snake, Bandana Snake, Cordarilla, Night Tiger, Housesnake, Salmon Snake (Worrell, 1963), Philippine Ratsnake (Jenkins, 1983), and Brown Catsnake (O’Shea, 1990). The name Philippine Ratsnake is a misnomer widely used on Guam. The snake does not occur in the Philippines, although its arrival in Guam coincided with an influx of Filipino immigrants. 


\section{MORPHOLOGY}

A snake that forages in vegetation has greater mobility if it can minimize its mass and distribute that mass over many support points. A slender body form also facilitates cantilever movements, in which a snake extends its body to bridge gaps in the vegetation. A thin body reduces cardiovascular problems associated with blood pooling when the snake is vertical (Lillywhite, 1987). Thus it is not surprising that arboreal snakes are universally slender in build (Guyer and Donnelly, 1990; Lillywhite and Henderson, 1993). The semiarboreal Trimeresurus flavoviridis, or Habu, is relatively slender for a viper, but the Brown Treesnake has an even lower mass relative to its length (Fig. 2.2). This extreme morphology indicates that the Brown Treesnake is well adapted for an arboreal existence.

The Brown Treesnake attains an unusually large size for an arboreal colubrid: up to $2.3 \mathrm{~m}$ total length in females, up to $3.1 \mathrm{~m}$ in males. Most large Brown
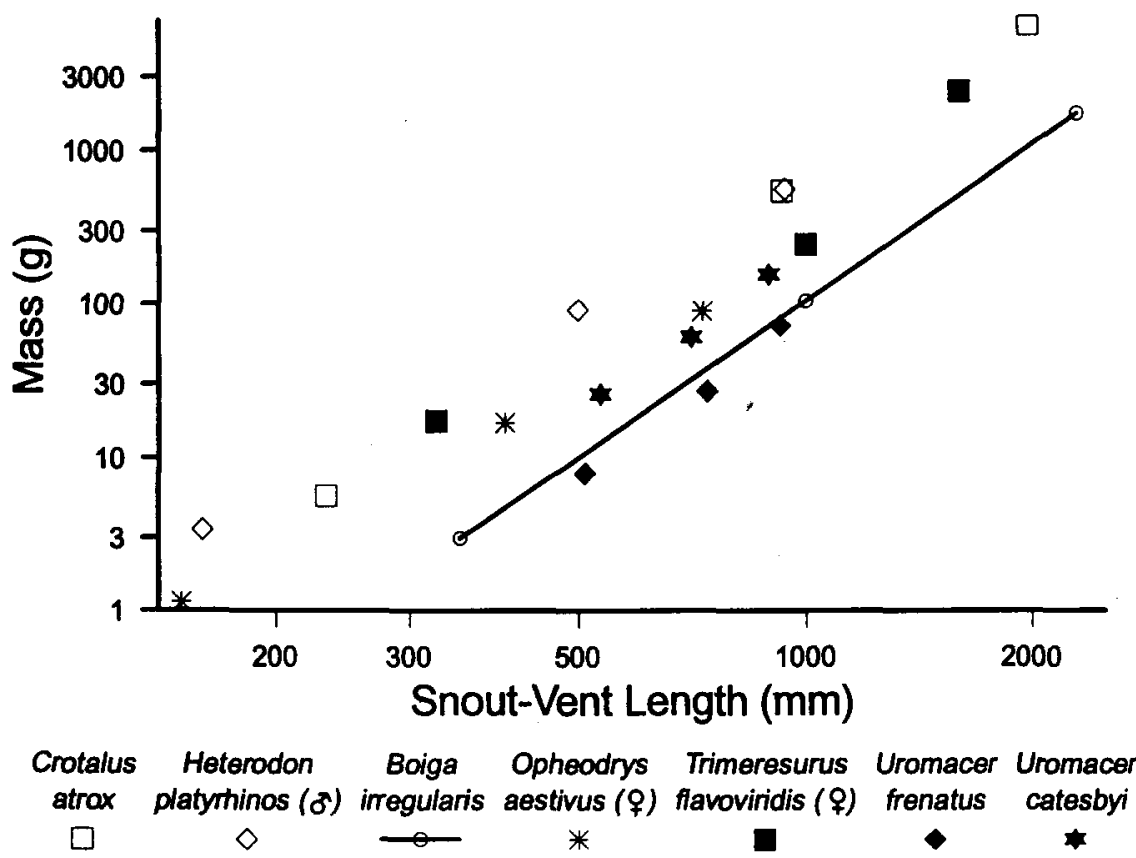

Figure 2.2 Mass-length relationships for a sample of snakes. To minimize overlap of regression lines, only three points are shown for each species: size at hatching, typical size, and maximum size (Uromacer data do not include hatchlings). The regression line for Boiga emphasizes that it is lower in relative mass than all species shown except Uromacer frenatus. U. catesbyi and Opheodrys aestivus are also arboreal. (From Andrews, 1982; Plummer, 1985; Nishimura et al., 1988; Nishimura and Kamura, 1989; R. Henderson, pers. comm., 1995.) 
Treesnakes are found on the ground, probably because snakes near the maximum size are too heavy for arboreal foraging (Rodda, 1992). Sexual dimorphism is expressed only as a difference in maximum size attained (Rodda et al., 1996b); the sexes do not differ in proportions.

Arboreal snakes tend to have long tails (Guyer and Donnelly, 1990), although the evolutionary advantage accrued by elongation of the tail rather than the body is not known (Lillywhite and Henderson, 1993). However, the Brown Treesnake exhibits neither an especially long tail nor any sexual dimorphism in tail length (Fig. 2.3). The tip of the tail is missing in about $8 \%$ of the specimens captured in Guam. The relative length of the Brown Treesnake's tail is less than those of 13 arboreal and semiarboreal snakes from a lowland site in Costa Rica (Guyer and Donnelly, 1990). In addition to being short, the Brown Treesnake's tail is slender. A slender tail may limit the size of hemipenes; those of the Brown Treesnake are nonbifurcate and relatively small.

Although the neck of most arboreal snakes exhibits evolutionary slenderization, the head usually does not, presumably because reduction in head size would limit the size range of potential prey. The Brown Treesnake conforms to this pattern: the head is conspicuously larger than the neck, especially among the more

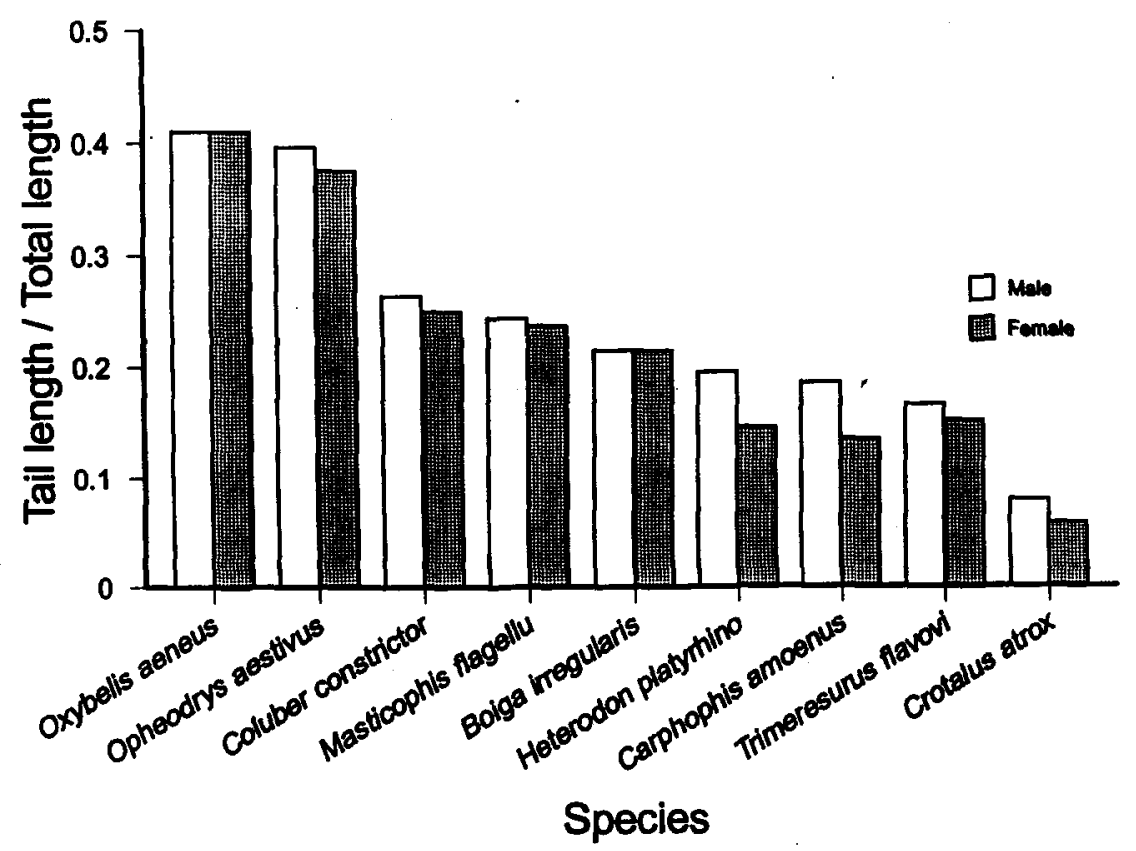

Figure 2.3 Proportional tail length for a sample of snakes. The two long-tailed species and Boiga are arboreal; Trimeresurus flavoviridis is semiarboreal; Carphophis is fossorial; and the others (Coluber, Masticophis, Heterodom, and Crotalus) are terrestrial. (From Klauber, 1972; Kaufman and Gibbons, 1975; Palmer and Braswell, 1976; Ernst and Barbour, 1989.) 
gape-limited juveniles (Fig. 2.4), Gape in the Brown Treesnake is expanded by exceptionally large quadrate bones (Chiszar et al., 1991). Many arboreal snakes, including the Brown Treesnake, make up for their slender neck and anterior body with extremely elastic soft tissues to allow passage of large prey. To enable cantilever movements without relying on the support of inelastic skin, the Brown Treesnake has developed muscular enlargement of the anterior body in the dorsoventral plane. When threatened, the Brown Treesnake exaggerates its profile by highlighting its large dorsoventral aspect with lateral compression of the body. This defensive behavior is exhibited by several species of arboreal snakes. Arboreal snakes often develop middorsal scales that are transversely enlarged and tightly attached to underlying connective tissue, presumably an additional adaptation to assist in cantilever movements (Lillywhite and Henderson, 1993); this trait is evident in some but not all Brown Treesnakes and is not pronounced in snakes from Guam.

Relative to other snakes, arboreal snakes tend to have a relatively anterior placement of the heart (Lillywhite, 1987), and they generally have large eyes and prehensile tails, as does $B$. irregularis. Unlike the boids, with their massive prehensile tails, Boiga can use its slender tail to grip thin branches. Brown treesnakes may anchor the tail with a half hitch when they are threatened with being shaken or pulled from trees.

(a)
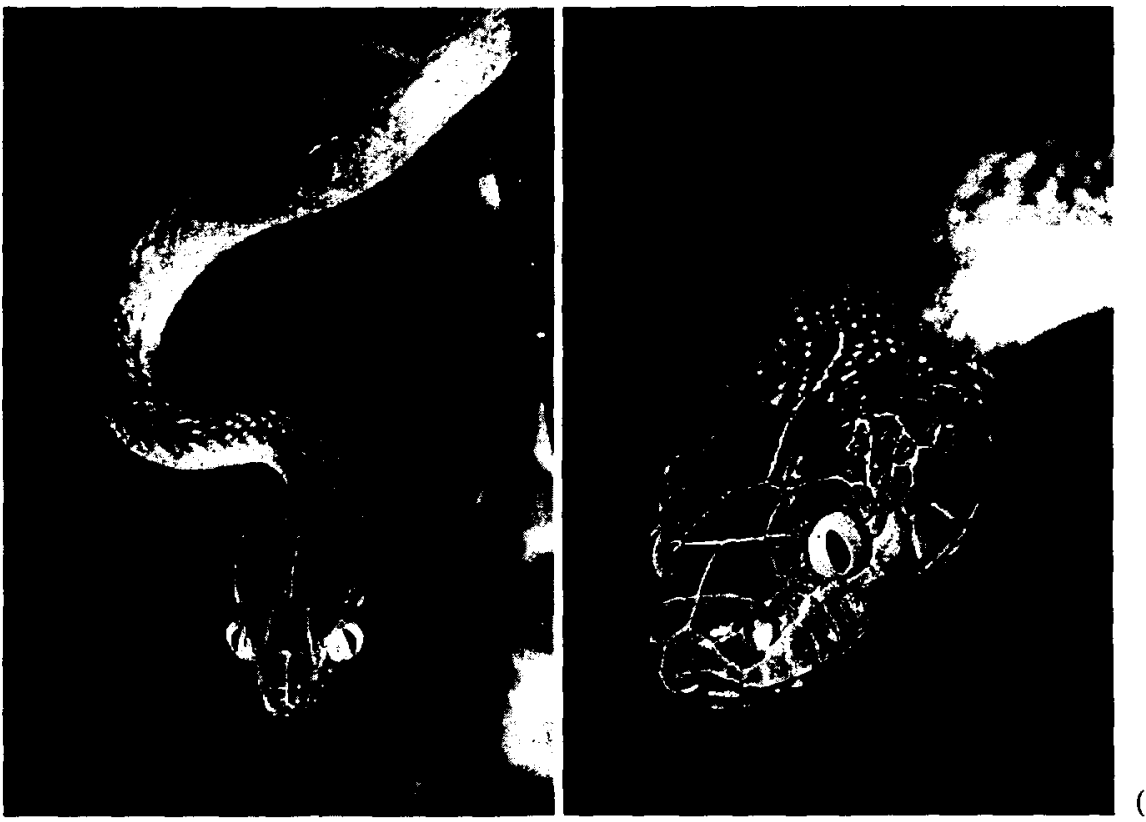

Figure 2.4 Head shapes in relaxed juvenile (a) and adult (b) Boiga irregularis. 
The Brown Treesnake has the elliptical pupil characteristic of both its genus and most other nocturnal snakes, but it lacks the reflective layer in the retina possessed by some nocturnal snakes to enhance vision in dim light (Henderson, 1993); thus, it has no eye shine. In contrast to diurnal species, which are characterized by attenuate snouts and frequently have binocular vision, nocturnal arboreal snakes tend to have blunt snouts and laterally directed eyes (Lillywhite and Henderson, 1993). The head shape of the Brown Treesnake conforms to the nocturnal arboreal archetype (Fig. 2.4).

Lillywhite and Henderson (1993) noted that nocturnal arboreal species tend to have a blotched color pattern, which disrupts the otherwise conspicuous serpentine form. This would be especially beneficial to Brown Treesnakes, which sometimes rest in exposed sites during daylight hours. Diffuse markings may provide further crypsis in that they resemble the dapples of moonlight and sunlight that penetrate the forest canopy.

The venom apparatus of the Brown Treesnake is associated with the snake's phylogeny rather than with its ecology. As is characteristic of the subfamily Boiginae, the dentition of the Brown Treesnake's maxilla includes two or three posteriormost teeth with conspicuous grooves, which conduct Duvernoy's secretion into the tissue of the prey (see Kardong, this volume, Chap. 7).

\section{Scutellation}

All of the 120 specimens we examined from throughout the snake's range had one preocular, although Brown Treesnakes with two preoculars are found occasionally in the Solomon Islands (McCoy, 1980). There are two postoculars. Contact between the preocular and frontal is variable in $B$. irregularis in the Solomons (McCoy, 1980), although Kinghorn (1964) used this trait to distinguish B. fusca from B. irregularis in Australia. The frontal is about as long as it is distant from the tip of the snout. There are one to four temporals, 8-12 supralabials, and 10-16 infralabials. A loreal scale separates the nasal from the preocular. Dorsal scales lack keels but have two apical scale pits which vary in size and conspicuousness. There are 17-25 scale rows around the middle of the body and fewer rows around the body elsewhere. The anal scale is undivided, except perhaps in Brown Treesnakes inhabiting New Guinea, where both divided and undivided anals have been reported (Parker, 1982; Mengden and Cogger, n.d.). The number of subcaudals varies from 65 to 130, although Kinghorn (1964) claimed B. fusca has fewer than 104 and $B$. irregularis has more than 102 . Using this criterion, both species are present in the Solomons, New Guinea, the Moluccas, and Sulawesi, but not in Guam (Guam range, 110-125). The subcaudals are uniformly divided in Brown Treesnakes inhabiting the Solomon Islands (McCoy, 1980) and, according to most reports, Australia (Worrell, 1963; Gow, 1976; Storr et al., 1986, for B. fusca). Kinghorn (1964) specified that subcaudals in some Australian B. irregularis lacked 
divisions, as is reported for the species in New Guinea (Parker, 1982; Mengden and Cogger, n.d.).

\section{BEHAVIOR}

\section{Activity}

Like other members of the genus, $B$. irregularis is nocturnal. Although most of Guam's snake-caused power outages occur at night (Fritts et al., 1987; Fritts and Chiszar, this volume, Chap. 4), some outages occur during the day, especially in the morning hours (see below). Radiotelemetered snakes are occasionally detected moving in the early hours of the day (M. Santana-Bendix, pers. comm., 1992); we have seen a few snakes moving in the vicinity of traps in the morning, and laboratory studies show Brown Treesnakes to be alert and responsive during the day (Chiszar et al., 1985; Chiszar and Kandler, 1986). Most movement, however, occurs at night.

The distribution of electrical power outages through the night suggests that Brown Treesnakes do not terminate their activity partway through the night as do Corallus hortulanus (Henderson, 1993). Outages peak at midnight and taper off in the morning hours (see Fritts and Chiszar, this volume, Chap. 4). We investigated Brown Treesnake activity during the first half of the night (2000-2400) by comparing the number of sightings at various times of night along a single transect that was surveyed repeatedly (Rodda, 1989). Although this method can be biased by progressive searcher fatigue, we found that mean sighting rates increased in each of four one-hour time blocks $(0.66,0.87,0.91$, and $1.69 / \mathrm{h})$ in a pattern similar to the pattern of electrical outages.

A folk wisdom staple on Guam is that Brown Treesnakes are active primarily or exclusively during rainstorms (rainstorms, which are usually brief in duration, occur in all seasons on Guam). Our visual census data do not support this belief; our sighting rates were lower (but not significantly so) when it was raining; and surveys conducted in the six hours following a rainstorm did not show elevated numbers of snake sightings compared with surveys during dry periods $(F=0.03$, $P=0.87)$. We attribute the folk wisdom about snake activity during rainstorms to the seasonality of Brown Treesnake activity (discussed below) and to a possible disinclination of snakes to cross roads except when nocturnal illumination is low, such as during heavy rainstorms.

\section{Thermoregulation}

Thermal data are available for only two individuals, both from Papua New Guinea (Johnson, 1975a). The snakes were surgically implanted with head and body thermocouples and subjected to natural and artificial heating. Both snakes selected 
temperatures of $34.8-36.1^{\circ} \mathrm{C}$, and tolerated slightly higher temperatures in their bodies than in their heads. The temperatures selected by these captive snakes are about $5^{\circ} \mathrm{C}$ warmer than the snakes can attain when they are active in nature (Eldredge, 1983). This may be a case in which thermal preferences are evolutionarily conserved (Rosen, 1991), or perhaps the snakes in Johnson's experiment were exhibiting behavioral fever in response to their surgery (Lutterschmidt and Reinert, 1990; Lutterschmidt and Rayburn, 1993). No experiments have been conducted to determine the critical thermal limits of the Brown Treesnake.

\section{Locomotion}

Studies on the exceptional locomotor abilities of Brown Treesnakes are summarized by Fritts and Chiszar in this volume (Chap. 4).

\section{Seasonality}

In Australia, Brown Treesnakes limit their activity to the warmer and wetter summer months (Covacevich and Limpus, 1973; Hoser, 1980; Armstrong and Pyke, 1991; Shine, 1991). A relatively humid atmosphere may be a physiological necessity for Brown Treesnake activity, as our captive snakes are unable to shed properly when the relative humidity falls below $60 \%$. In nature, they probably take shelter in damper microclimates (e.g., underground, in limestone crevices, and inside tree holes) to endure short periods of low humidity. Brown Treesnakes do not inhabit environments with chronic low humidity.

On Guam, some Brown Treesnake activity occurs in all months (Fritts, 1988). There are three sources of information on the seasonality of Brown Treesnake activity on Guam: power outages, envenomation reports provided by hospitals, and sighting rates from visual surveys (Fig. 2.5). Mean temperatures on Guam vary only a little more than $1^{\circ} \mathrm{C}$ annually (Fig. 2.5), and rainfall is thus considered the more important climatic factor. Brown Treesnakes appear to be more sensitive to the seasonal trend in rainfall changes than to the absolute amount. Division of the year into quarters of low, rising, high, and falling rainfall revealed a mild seasonal $(F=3.35, d f=3,274, P=0.0196)$ or monthly $(F=1.96$, $d f=11,266, P=0.032$ ) change in Boiga sightings, with greater activity during quarters of rising and high rainfall (Fig. 2.5). Snakebite reports showed essentially the same pattern (the two measures were significantly correlated: $r=0.72$, $P=0.008$ ), with higher numbers reported during the rising and high rainfall periods of the year. The bite averages for the months of rising and high rainfall were significantly greater than those for the rest of the year $(t=6.37, d f=10$, $P=0.001$ ), but power outages did not differ between seasons in that comparison ( $t=1.987, d f=10, P=0.075)$. Overall, then, the seasonality of Brown Treesnake activity seems to be tied to rainfall. This is consistent with the limitation of the snake to wetter localities (see below). The high surface-to-volume ratio dictated 

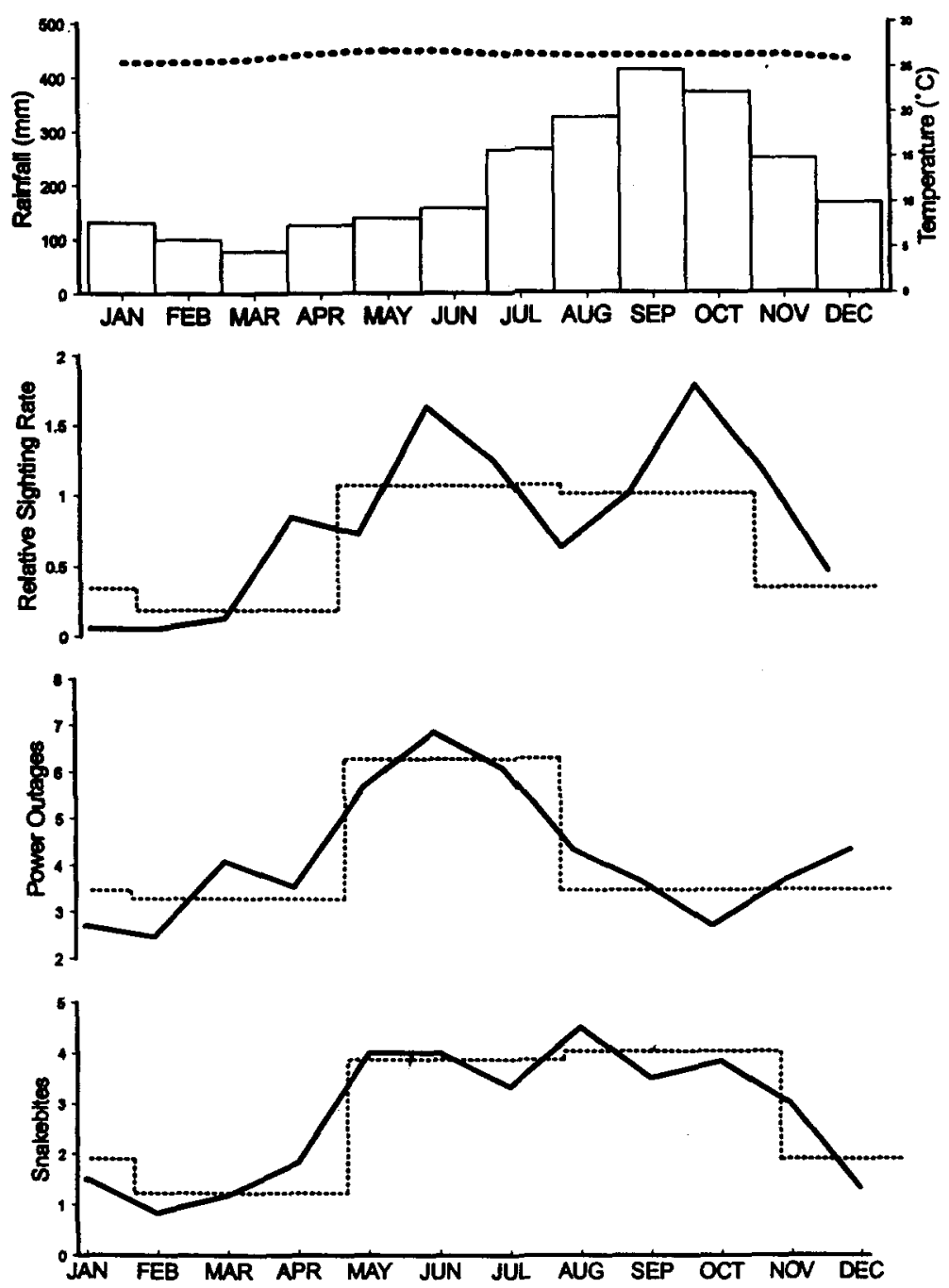

Figure 2.5 Phenology of Boiga activity based on sightings, power outages, and hospital visits by bite victims. The top graph shows the variable rainfall and nearly constant temperatures on Guam (Stanley, 1985). The other graphs show monthly (solid line) and quarterly (dashed line) rate averages for sightings, power outages, and snakebites. The sighting rates are statistically adjusted for searcher, site, and year (data collected 1988-1990). The sighting values are relative to an arbitrary annual average of 1.0 ; a monthly average of 0.5 does not denote a sighting rate one-half as great as a value of 1.0 on this scale. The power outage rates are based on the 13 year period 19 January 1978-18 January 1990. The bite records cover 6 years, 21 September 1986-20 September 1992. Bites reported to hospitals on Guam were probably undercounted in the earlier years of this period; thus the averages should not be taken literally as monthly totals. All samples are undoubtedly undercounts of the total number of bites and power outages that transpired. 
by the snake's extremely slender morphology may promote a moisture deficit during dry periods.

\section{Habitat Requirements}

In Australia, moisture and temperature appear to limit the Brown Treesnake's distribution to the warmer and wetter regions (Cogger and Heatwole, 1981; see also Sweeney, 1971; Henderson et al., 1978); they do not occur in the arid interior, and their southern limit roughly coincides with the frost line, near Sydney (Cogger, 1992). In Papua New Guinea, the Brown Treesnake occurs at elevations up to $1375 \mathrm{~m}$ (McDowell, 1984), about the elevation where occasional frosts are reported.

The habitat preferences of the Brown Treesnake have been quantified through visual surveys and radiotelemetry (Wiles, 1986, 1987b, 1988; Rodda, 1992; Santana-Bendix, n.d.). Snakes should occur more often in preferred habitats. Unfortunately, using sighting data for describing habitat preferences can bias one's conclusions. The snake may be common in dense foliage or grass but relatively difficult to see. Conversely, the snake's putative association with rocky areas (Ehmann, 1992) may be due primarily to the paucity of cover in that habitat and the tendency for shed skins (noticeable evidence of presence) to accumulate on protected rock walls. An analysis of 398 snake sightings from Guam indicated that the highest sighting rates occurred in tangantangan trees (Leucaena leucocephala); but this apparent association may be just a function of foliage type. At best, the tangantangan tree's small leaflets, which fold up at night, afford poor concealment, thus allowing searchers to detect the snakes more readily (Rodda, 1992). Visual sighting rates have been sampled from most terrestrial habitats within the snake's range, and the differences in sighting rates among habitat types could be the result of variation in visibility (Rodda and Fritts, 1992a).

We believe Brown Treesnakes prefer densely foliated arboreal habitats, although there is no evidence that they are limited to such places. To date, radiotracking data are available only for snakes inhabiting primarily forest areas. The radiotelemetry data show that Brown Treesnakes habitually travel through all types of forested and nonforested habitats. Within forested habitats they may travel on the ground. They also make extensive use of grasslands and shrublands (M. Santana-Bendix, pers. comm., 1991). The fact that they are sometimes killed by lawn mowers indicates that they use short-grass habitats. It seems probable, however, that they are less abundant in short-grass habitats than in forested habitats, especially during the day. We have marginally insignificant evidence $(P=0.077)$ that Brown Treesnakes are reluctant to venture into short grass or other exposed locations on bright moonlit nights (Rodda and Fritts, 1992a). In short-grass habitats, Brown Treesnakes will seek safety by climbing any type of structure (tree, power pole, building, etc.); climbing is less frequent when dense ground vegetation provides cover (Rodda, 1991). The radiotelemetry data show that Brown Treesnakes will cross substantial expanses of asphalt on a regular basis 
and without apparent hesitation. In addition, there are anecdotal reports of Brown Treesnakes swimming at night on the ocean surface above relatively deep water ( $>25 \mathrm{~m}$; G. Davis, pers. comm., 1989), but we have no practical way of estimating the frequency of this behavior. Brown Treesnakes do not appear to be habitat limited.

\section{Refugia}

Radiotelemetry studies (Wiles, 1986, 1987b, 1988; Santana-Bendix, n.d.) indicate that Brown Treesnakes spend their inactive daytime periods in all parts of the landscape. They have been observed in the tops of trees, among branches at high and low positions in the vegetation, in shrubs, on the ground, under rocks, and deep in subterranean crevices.

\section{Movements}

Data regarding the movements of Brown Treesnakes come from two sources: the radiotelemetry studies discussed above and recaptures of marked animals. Both methods are sensitive to sampling frequency. For example, the radio-tracking data showed home ranges of 3-6ha after 25 days of data collection, but much greater areas (10-30 ha) after additional months of monitoring. Single-night movements of up to $410 \mathrm{~m}$ were observed. The mean distance between daytime refugia was about $45 \mathrm{~m}$. Snakes rarely occupied the same refugium on sequential days but sometimes were in the same general area for several days. They were not observed to return to a regularly used refugium after more distant forays. The movements reported are greater in magnitude than any tabulated, in a recent review of nonmigrating snakes (Macartney et al., 1988). The Brown Treesnake's movements appear to be comparable in scale with those of the Sidewinder, Crotalus cerastes (Secor, 1992), although data are not yet available for an exact comparison.

Trap captures of marked animals provide movement histories that can be modeled using open population models (Rodda et al., this volume, Chap. 17) to estimate the percentage of the population that moves out of the sampled area over the trapping interval. We used 1.2-1.6ha trapping arrays to estimate the nightly immigration rates of snakes at two locations over three 40 day sampling periods. At our trap site on Orote Peninsula, Guam, $4.5 \%(S E=1.4 \%)$ of the population immigrated per night in 1990 and $6.8 \%(S E=1.5 \%)$ in 1991. At our Northwest Field site in 1992 the comparable value was $5.7 \%(S E=3.3 \%)$. These high rates of daily population turnover indicate that either the snakes' home ranges were much larger than our trapping arrays, or the snakes had no home ranges and wandered continuously. Both hypotheses are somewhat supported by the radiotelemetry data, perhaps indicating that some snakes wander and some remain within very large home ranges. Recent recaptures of snakes marked 8-10 months earlier suggest that the recaptured individuals had large home ranges. This infer- 
ence is based on the unexpectedly large number of recaptures. If about $5 \%$ of the snakes had left the area "permanently" each night, as indicated by the short-term mark-recapture data, a negligible number $(0.00002 \%)$ should have remained in the study area 8-10 months later. Yet with only a modest recapture effort, we captured 13 of $80(16 \%)$ snakes marked in the same area almost a year previously. This suggests that Brown Treesnakes do have home ranges, although these must be unusually large, indeed much larger than the trapping arrays we used. This evidence does not disprove the possibility that some of the snakes that were not recaptured wandered rather than having large home ranges.

\section{Social Interactions}

Although snakes are not usually considered social, they may react to each other at a distance by avoiding each other or areas where other snakes have been, or they may be attracted to conspecifics, especially for mating or finding suitable refugia (Pendleton, 1947; Covacevich and Limpus, 1973; Hoser, 1980). The anecdotal evidence from Guam and the native range suggests that Brown Treesnakes tolerate and may even seek out others to find suitable refugia; however, aggregations of Brown Treesnakes in trees and rock crevices on Guam (e.g., Savidge, 1986) exhibited no apparent social structure. Snakes of all sizes, sexes, and maturation stages cohabited apparently randomly.

We also tested for social responses by analyzing the composition of groups of snakes found in single traps. The frequency distribution of group sizes closely approximated a Poisson distribution $\left(G_{a d .}=7.38, d f=4, P=0.12\right)$, indicating that snakes were neither avoiding nor seeking to enter traps that already contained a snake (Fig. 2.6). It is possible, however, that this test is misleading because it pools snakes of both sexes. For example, a male snake might seek to enter a trap with a female but avoid entering a trap already occupied by a male. This was not the case (Fig. 2.7); the sexual composition of groups did not differ statistically from random when comparing either the sex ratios of groups of different sizes $(G=3.047, d f=3, P=0.38)$ or the specific makeup of pairs $\left(G_{a d j}=1.32\right.$, $d f=2, P=0.52)$ or trios $\left(G_{\text {adj }}=6.03, d f=3, P=0.11\right)$. In all cases, the insignificant deviation observed was opposite in direction from that predicted by a social interaction hypothesis. That is, there were numerically (but not statistically) fewer heterosexual combinations and more homosexual combinations than expected by chance. These data were collected in October and November, and it is possible that social attraction occurs at other times of year. Nonetheless, we have seen no other evidence to indicate that social interactions are an important component of Brown Treesnake behavior.

\section{Defensive Behoviors}

The Brown Treesnake's first line of defense against predators is to avoid detection by crypsis or concealment, or to cease movement in response to a distant pre- 


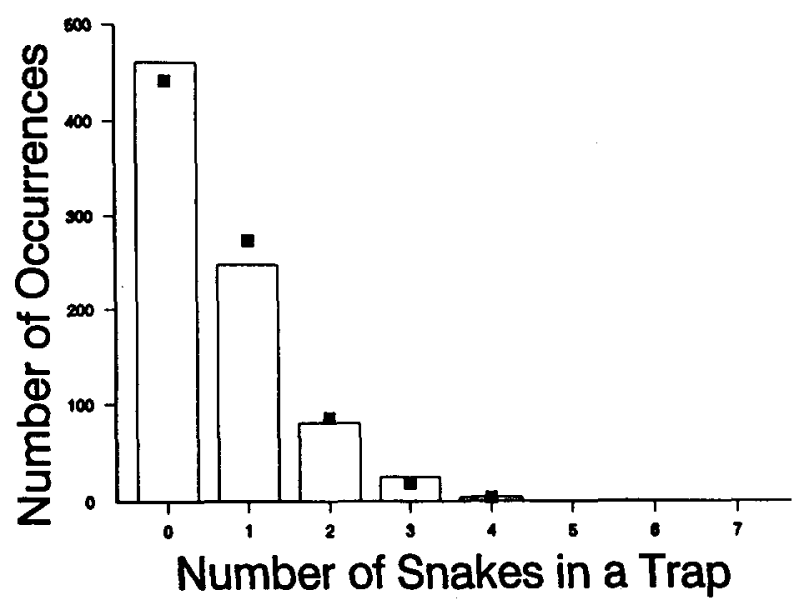

Figure 2.6 Distribution of snake group sizes captured in single traps at Orote Point, Guam, 1992. The square markers indicate expected frequencies under the assumption of randomness (Poisson distribution).

dator. It spends most daylight hours motionless, concealed by its cryptic coloration and the cover of natural vegetation. Although it may bask at the top of the canopy on some days, it often basks just under the first layer of leaves, where it will be warmed by the sun but not exposed directly to sunlight or visual predators. When discovered and closely approached, Brown Treesnakes usually crawl away rapidly and if necessary drop from the tree to avoid capture. Generally, only when cornered or held does a Brown Treesnake coil and defend itself aggressively.

The Brown Treesnake has gained a degree of notoriety because of the dramatic and protracted coiling and striking behavior it exhibits when cornered (Johnson, 1975b; Cogger, 1992). Recently captured snakes sometimes maintain an elevated strike pose for more than an hour after a human has passed the cage. For an arboreal species, the Brown Treesnake may be exceptionally willing to strike, yet the form of its display is similar to that of many other arboreal snakes (Greene, 1979). The defensive display involves increasing the dorsoventral dimension by laterally compressing the anterior part of the body while drawing it into an exaggerated S-shaped coil, spreading the posterior part of the head, and sometimes opening the mouth. Particularly noticeable in the Brown Treesnake is the flaring of the quadrate bones when the snake is aroused (Chiszar, 1990). This may increase the apparent size of the snake's head and cause it to resemble the triangular head of a viper. Only on the island of Sulawesi, however, does the range of the Brown Treesnake overlap with any viper models in a putative mimicry complex (i.e., with Trimeresurus (=Tropidolaemus) wagleri). The distributions of other Boiga species overlap broadly with vipers, and any mimetic relationship with vipers could be a phylogenetic carryover. 

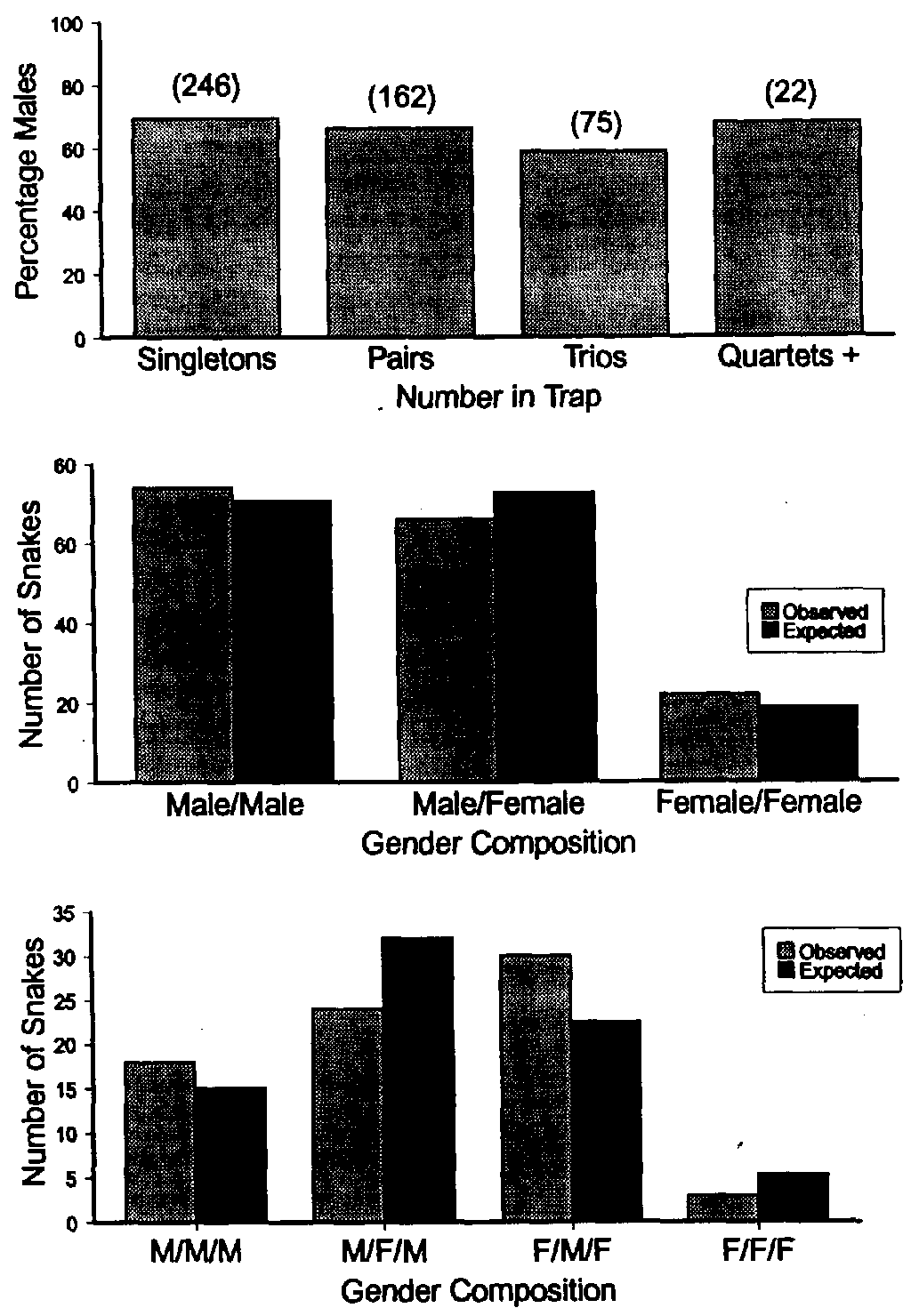

Figure 2.7 Gender composition of snake groups captured in traps at Orote Point, Guam, 1992. The top graph indicates that the sex ratio of solitary captures did not become progressively more male-biased in larger aggregations of snakes, which would be expected if males were attracted by trapped females (sample sizes shown parenthetically). Expected distributions of the sexes in the lower graphs were based on random entrance of individuals based on the overall sex ratio exhibited by the marginal totals. 


\section{DIET}

Snakes of the genus Boiga eat a wide variety of vertebrates. The smaller catsnakes usually focus on frogs and lizards; the larger ones eat more mammals and birds (Greene, 1989). The consumption of endotherms is relatively rare in tropical snakes. Duellman (1990) reviewed the diets of 106 species of colubrid snakes from Neotropical sites and found that mammals were included in the diets of only $14 \%$ of the species, and birds were included in the diets of only $9 \%$. The larger Boiga species often exhibit an ontogenetic dietary shift from ectotherms to endotherms, most clearly documented in the Brown Treesnake (Savidge, 1988; Greene, 1989). On Guam this ontogenetic or size shift is more or less mandatory because the available prey of a size suitable for a small snake are ectotherms, and most large prey are endotherms. Before the introduction of the tiny frog Litoria fallax (McCoid, this volume, Chap. 37), all appropriate ectothermic prey for the Brown Treesnake on Guam were lizards. Frogs have not been found in significant numbers of snake stomachs on Guam, but frogs are regularly eaten by Brown Treesnakes in Queensland, Australia (Shine, 1991).

Greene (1989) noted a tendency for large Brown Treesnakes on large islands (e.g., New Guinea) to eat mammals, whereas those on smaller islands consume primarily birds. This may be due to the relative availability of prey in these habitats. Nowhere, however, are Brown Treesnakes dietary specialists. In the wild, small Brown Treesnakes on Guam eat primarily lizards, but in captivity they unhesitatingly consume small mammals. They eat not only a full spectrum of the available live vertebrates on Guam, including eggs, young, and adults (Savidge, 1988), they also ingest or attempt to ingest a wide variety of items not normally sought by snakes. We have records of snakes eating or attempting to swallow dog food, chicken bones, raw hamburger, maggot-infested rabbits, paper towels, spareribs, rotting lizards, ornamental betel nuts, larger conspecifics, human babies, dog placentas, and soiled feminine hygiene products (see also Fritts and McCoid, this volume, Chap. 6; Chiszar, 1990).

Although Brown Treesnakes may feed opportunistically on almost any protein source, some items may be preferred or more easily captured. The best data were obtained by B. E. Smith and T. H. Fritts, who found anoles in the stomachs of snakes with much greater frequency than the anoles were collected by herpetologists sampling the same area (Fig. 2.8). The anole is now rare on Guam except in limited urban areas (Rodda et al., 1991), possibly as a result of its vulnerability to the snake. Unvigilant lizards sleeping at night in exposed sites in the foliage are especially vulnerable to the systematic arboreal searching technique of foraging Brown Treesnakes (Rodda, 1992), and in Guam only anoles exhibit such sleeping behavior. In most of the Brown Treesnake's native range, agamid lizards sleep exposed in foliage, a habit that may account for the disproportionate occurrence of these lizards in the digestive tracts of Australian Brown Treesnakes (Shine, 1991). 


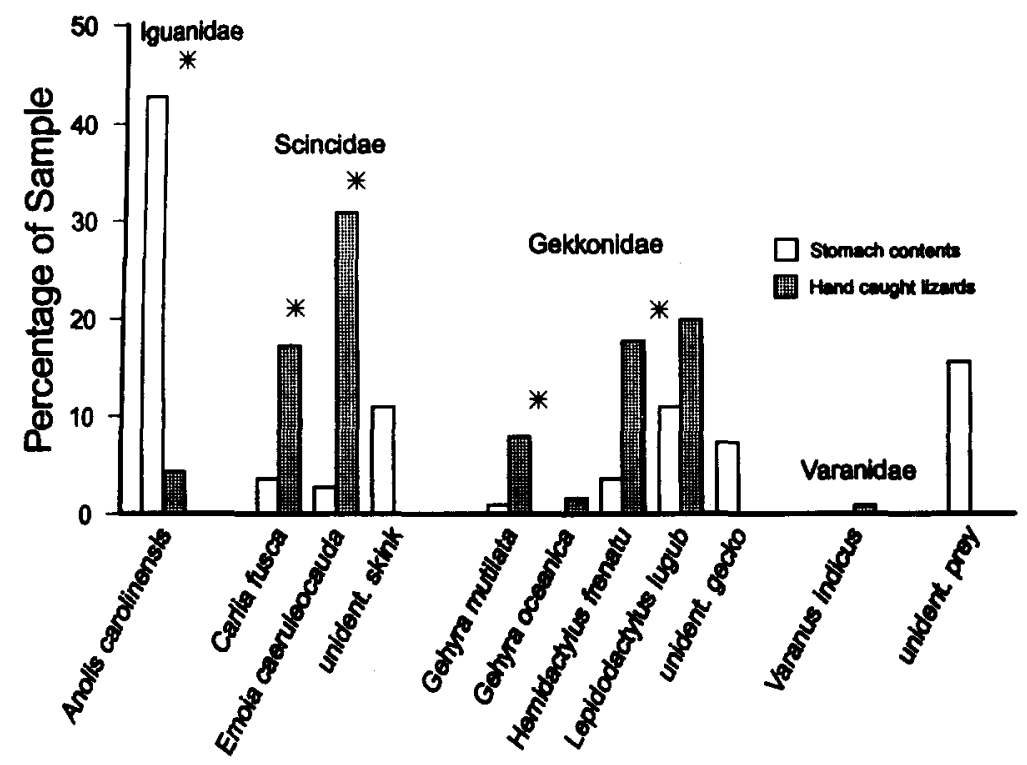

Figure 2.8 Frequencies of potential and actual lizard prey taken by snakes from Northwest Field, Guam, 1985 (From B. E. Smith and T. H. Fritts, unpubl. data). Asterisks denote significant $(P<0.05)$ differences between the percentages among lizard populations and predator stomachs. Potential prey were estimated by the frequency of each species in a syntopic hand collection of 494 lizards; actual prey were those of 108 food items collected from 168 snakes (of which 84 had empty stomachs). Each food item was counted as a unit.

On Guam, the diet of Brown Treesnakes varies among sites (Savidge, 1988) and appears to have changed in recent years in response to the disappearance of endothermic prey (Fig. 2.9). Although native birds have disappeared from Guam's forests, introduced and domestic birds are found in urban areas and rats are common, especially near livestock and domestic fowl. In contrast to the richness and variety of prey available in these altered habitats (Fig. 2.9), forested areas on Guam during the sample period (1985-1991) provided relatively few prey species for Brown Treesnakes. In samples collected on Guam since 1989, small lizards have constituted the bulk of the Brown Treesnake's diet (Fig. 2.9). Any Brown Treesnake we collect while it is foraging arboreally is classified as a "tree snake." These tend to be juveniles, and in recent samples they have eaten approximately equal numbers of geckos and skinks. Snakes collected while they are foraging on the ground ("ground snakes") are usually large adults that subsist almost exclusively on terrestrial skinks, especially the introduced skink Carlia cf. fusca (Fig. 2.9). In previous decades, large Brown Treesnakes on Guam probably fed on the large geckos Perochirus ateles and Gehyra oceanica, but large geckos have now been extirpated from most areas of Guam (Rodda and Fritts, 1992b). The dietary 


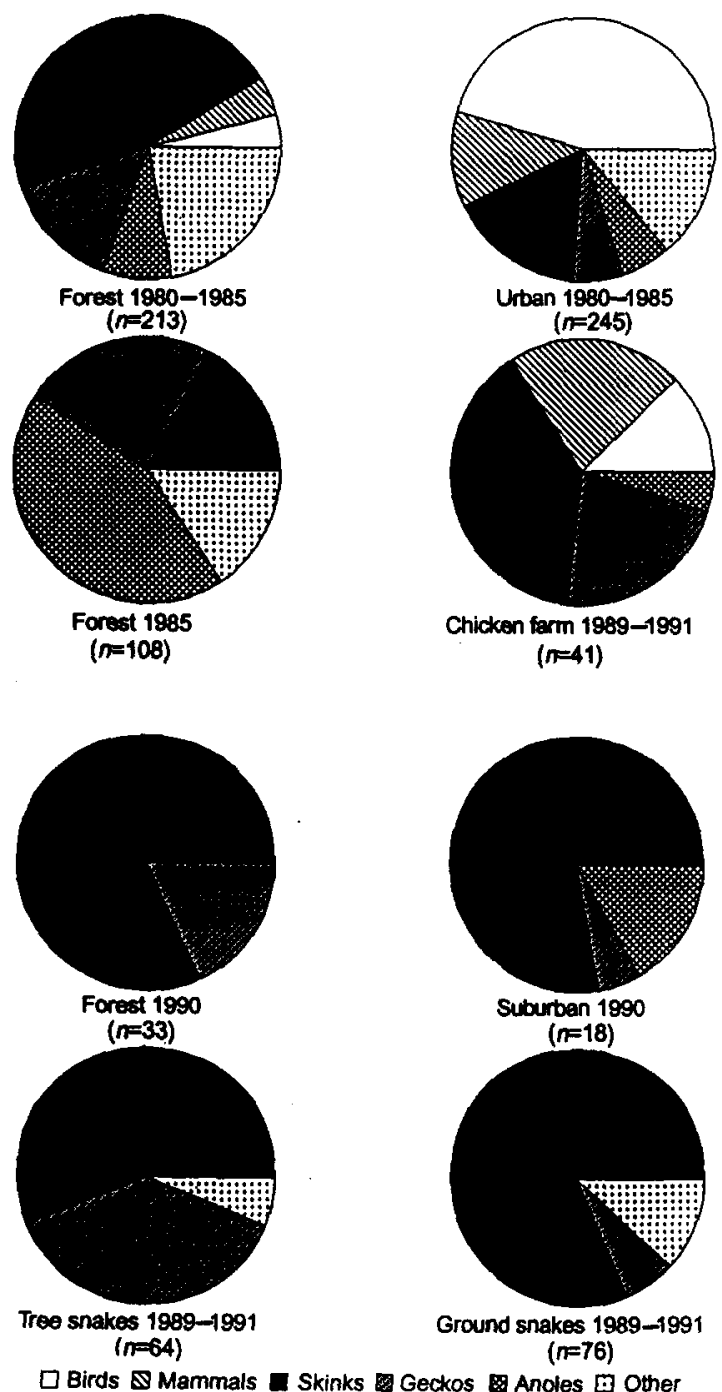

Figure 2.9 Summary of our data and those from other Guam studies detailing major dietary groups represented in analyses of B. irregularis digestive tracts. Most "other" material was reptile eggs or unidentified pieces of reptile skin. Thus reptiles constituted the majority of prey items in all samples except the 1980-1985 urban sample. The number of snakes examined for each sample was substantially larger than the number of food items listed parenthetically as the sample size. In addition to our own studies we have included those of J. A. Savidge (1988) for urban and forest areas (1980 1985) and those of T. $H$. Fritts and B. E. Smith for forest 1985 (Fig. 2.8).

variation seen in Brown Treesnakes from different Guam venues (Fig. 2.9) is an example of the opportunistic habits of this species.

The Brown Treesnake feeds on both nocturnally active (e.g., geckos) and inactive prey (e.g., sleeping diurnal lizards, eggs). It appears to capture geckos and rats using ambushing tactics, whereas eggs and inactive prey are obtained by slow, systematic searching (Rodda, 1992). One terrestrial foraging mode not exhibited by the Brown Treesnake is fast pursuit of fleeing prey.

Prey recognition is described in Chiszar, 1990. Venom is not used to kill prey (Kardong, this volume, Chap. 7); instead, small prey items are swallowed directly 
and larger prey are killed by constriction (Chiszar, 1990). The Brown Treesnake is exceptional for a nonviper in occasionally consuming meals as large as $70 \%$ of its mass (Chiszar, 1990). We have no measure of the cumulative amount of food normally ingested by wild snakes, but captive Brown Treesnakes will maintain a monthly level of consumption equal to $40 \%$ of their body mass (Collins, 1992); this is consistent with the $450 \%$ per year estimated for rattlesnakes that are active year-round (Klauber, 1972).

\section{REPRODUCTION AND DEVELOPMENT}

\section{Seasonality}

Despite the relatively constant climatic conditions in tropical areas, many if not most tropical snakes produce young more or less synchronously at a particular season (Fitch, 1982; Seigel and Ford, 1987). In the highly seasonal environments of Australia, Brown Treesnake reproduction occurs during the wetter, warmer summer months (Shine, 1991). The seasonality of reproduction in the Brown Treesnake on Guam is not known. Females with enlarged follicles or oviductal eggs have been found in January, February, April, May, June, July, and October (McCoid, 1994), suggesting that reproduction may occur at any time on Guam. Reproduction may be synchronous at a particular Guam venue but dependent on rainfall, and therefore may vary seasonally from year to year. Detection of seasonal reproductive cycles on Guam is hampered by the conspicuous rarity of gravid females ( $<0.5 \%$ of snakes sampled), presumably because gravid females are less active or more secretive (Fitch, 1960, 1987). J. D. Groves (1974) noted that a captive $B$. blandingi female left her normal arboreal perch and went to the bottom of the cage, where she remained without eating for six to eight weeks prior to oviposition. This suggests that gravid Brown Treesnakes may be undercollected because they become reclusive and inactive in that condition.

Hatchling snakes appear throughout the year (Fig. 2.10). Variation in percentages of hatchlings is insignificant for both bimonthly $(G=9.125, d f=5$, $P=0.10)$ and quarterly comparisons $(G=5.25, d f=3, P=0.16)$. We tentatively conclude that some reproductive activity occurs under appropriate conditions at all times of year.

\section{Courlship and Mating}

Neither courtship nor mating has been observed in the wild. D. Chiszar (pers. comm., 1995) described the courtship of captive Brown Treesnakes as being similar to that of most colubrids (Gillingham, 1987), with the male mounting the female, rubbing her body with his chin, and progressing in a jerky motion toward her head while attempting to lift her tail with his tail. Copulation has not yet been 


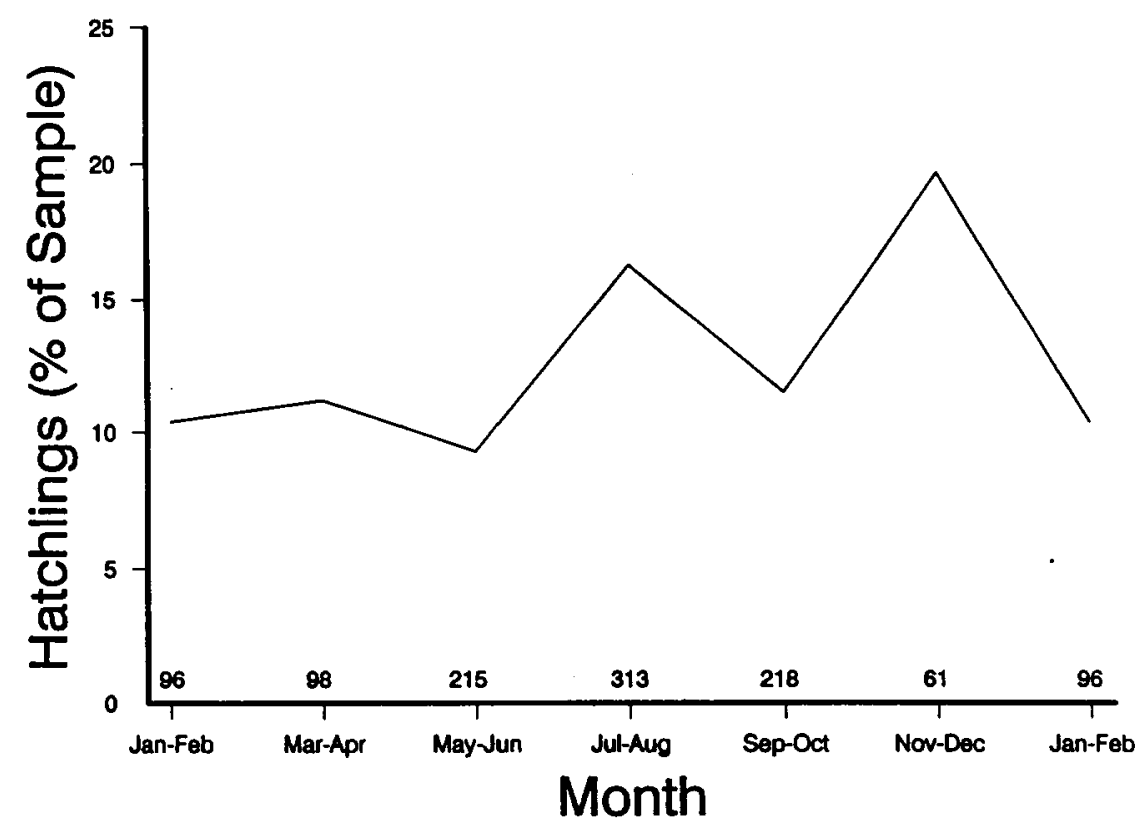

Figure 2.10 The bimonthly average fraction of hatchlings in samples of Brown Treesnakes from Guam, 1983-1987 (sample sizes are shown immediately above abscissa). Note that Jan.-Feb. appears at both ends of the scale.

observed. Attempts to pheromonally stimulate courtship in captive snakes have not been successful (Mason, this volume, Chap. 13).

Snakes are renowned for their ability to store sperm (Saint Girons, 1975); some females have produced viable young after being in isolation for six years (Haines, 1940). This phenomenon has not been investigated systematically in Boiga, but anecdotal reports seem to affirm the phenomenon for B. dendrophila (J. D. Groves, 1973 ) and B. multomaculata (Kopstein, 1938). We presume that any adult female that has mated could potentially start a new population.

\section{Eggs}

Despite the abundance of Brown Treesnakes on Guam (Rodda et al., this volume, Chap. 17), we have found few clutches of eggs in the field. Guam's Division of Aquatic and Wildlife Resources has a file record of a clutch of eggs found in a tree hole. There is also an unconfirmed report of a clutch of snake eggs found in the axilla of a coconut frond. One nest was found in a solution hole on a limestone cliff face on Guam. Perhaps most eggs are laid underground, as has been reported to be the case in Australia (Ehmann, 1992). 
Zwinenberg (1978) reported clutch sizes of 4-12 eggs. Parker (1982) reported that most gravid females in New Guinea held 7 eggs, occasionally 8. Based on museum specimens with enlarged follicles or oviductal eggs, Shine (1991) estimated the average clutch size among 21 gravid females from Australia to be 5.5 eggs $(S D=2.2)$. There was a significant correlation between maternal size and number of eggs $(r=0.69, P<0.05)$ in the Australian specimens. There is evidence of multiple clutches per reproductive season in B. blandingi (F. Groves, 1973). The numbers of enlarged follicles in Boiga in Guam frequently exceed the clutch sizes expected on the basis of female size; it is possible that some of the smaller follicles contribute to a second clutch. Except for snakes in Australia, where females appear to lay once annually (Shine, 1991), nothing is known about the frequency of egg laying in Brown Treesnakes.

We know the dimensions and hatching conditions of eight eggs from Australia (two clutches; Shine, 1991) and eight eggs from Guam (one clutch; McCoid, 1994). The Australian eggs were longer (52-56 vs. $43 \mathrm{~mm}$ ) and narrower (15-17 vs. $23 \mathrm{~mm}$ ) than the Guam eggs. The dimensions given for Brown Treesnake eggs from Papua New Guinea (Parker, 1982) match the Guam eggs in length but are intermediate in width.

The Australian eggs hatched after 76 days (incubated at $30^{\circ} \mathrm{C}$ ) and 90 days (incubated at $25^{\circ} \mathrm{C}$ ), while the Guam clutch produced one live hatchling after 94 days (daily range $25-30^{\circ} \mathrm{C}$ without controlling temperature). These data on incubation periods are similar to the few data for other Boiga species (Kopstein, 1938; F. Groves, 1973; J. D. Groves, 1974; Cox, 1991), although incubation periods for $B$. multomaculata are reportedly shorter, ranging from 60 days (Cox, 1991) to 65-67 days (Kopstein, 1938). The Guam embryos (seven full term, all female) were smaller and weighed less than any hatchlings that have been found in the wild on Guam. More data are needed to assess the reproductive biology of the Brown Treesnake.

\section{Size}

On Guam, the snout-vent lengths (SVL) of the smallest snakes found in the wild were $330-350 \mathrm{~mm}$. One juvenile of $430 \mathrm{~mm}$ SVL exhibited an umbilicus that had not yet closed. The lengths of these putative hatchlings are larger than comparable measurements taken from Australian snakes (Gow, 1976; Shine, 1991). We collected data on lengths and umbilical scar condition (ordinal) for 36 snakes bearing umbilical marks. The average size of those with a "conspicuous scar" was $572 \mathrm{~mm}$ SVL (range 350-690). Twelve snakes with "faint" scars averaged $625 \mathrm{~mm}$ SVL (range 525-710). As the scars grow over they become "notched" in appearance, and eight snakes with notched scars averaged $629 \mathrm{~mm} \mathrm{SVL}$ (range 590-705). Taken together, these data suggest that most hatchlings smaller than about $625 \mathrm{~mm}$ SVL show evidence of their umbilici; therefore, we use $625 \mathrm{~mm} \mathrm{SVL}$ as the length that distinguishes hatchlings among Guam snakes. 
Brown Treesnakes on Guam exhibit larger hatchling, maturation, and maximum sizes than those reported from the native range. Although Worrell (1963) stated that Brown Treesnakes in Australia sometimes exceed 7 feet, all recent authorities have listed the maximum length of Australian Boiga as 6 feet or $2 \mathrm{~m}$ (Kinghorn, 1964; Gow, 1976; Storr et al., 1986; Cogger, 1992; Ehmann, 1992). Ehmann (1992) stated that Boiga fusca can reach $2.0 \mathrm{~m}$, in length, but Boiga irregularis can grow to only $1.6 \mathrm{~m}$ (although Shine, 1991, lists a $1.63 \mathrm{~m} \mathrm{SVL}$ specimen from the range of $B$. irregularis [NSW] that probably exceeded $2 \mathrm{~m}$ in total length). Brown Treesnakes in New Guinea attain lengths of at least $2.3 \mathrm{~m}$ (Parker, 1982). Guam specimens reach at least $3.1 \mathrm{~m}$.

\section{Growth}

Information on the growth rates of wild snakes is limited to data gathered from 36 medium-sized snakes that were recaptured on Guam 8.8-16.3 months after their initial capture (Fig. 2.11). The males exhibited marginally insignificantly greater and significantly more variable growth than the females (mean male growth rate $16.8 \mathrm{~mm} /$ month $[S D=7.7]$ vs. $13.1[S D=3.3]$; $t$ for unequal variances $=1.96, d f=30.9, P=0.059)$. The absolute growth rate is generally highest for young reptiles (Andrews, 1982), but a decline in growth rate at larger

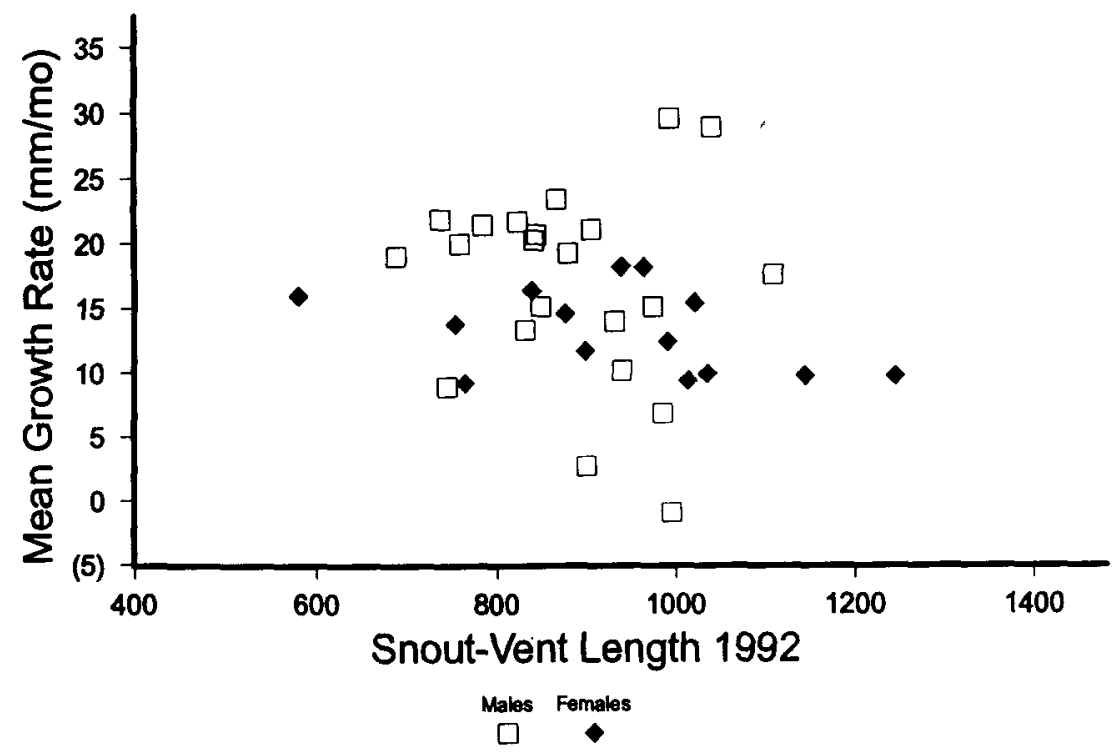

Figure 2.11 Growth rates for 36 Brown Treesnakes in relation to their original snout-vent length (SVL). Values reflect growth rates from time of initial capture to time of recapture, a period of 8.8-16.6 months (Guam, 1992-1993). 
sizes is not evident in this small sample. Data on a wider range of snake sizes are needed to characterize the growth of Boiga on Guam.

\section{Maturation}

In its native range (excluding Australia) the Brown Treesnake is reported to mature at around $750 \mathrm{~mm}$ SVL (Greene, 1989). For Australian Boiga, Shine (1991) reported minimum maturation sizes of 624 (males) and $637 \mathrm{~mm}$ SVL (females); the highest minimum maturation size was $850 \mathrm{~mm}$ SVL for males from the Northern Territory. These sizes are substantially smaller than those of Guam snakes with a mature internal anatomy. We examined 783 specimens to determine gonad mass, sperm presence and location, and convolutions of the vas deferens or thickening of the oviducts. Based on the distribution of conditions in snakes of varying sizes, we chose the following criteria as indications of maturity: males, mature if testis mass $>\mathbf{0 . 0 8} \mathrm{g}$ or sperm present and vas deferens convoluted, or, if information was lacking on sperm presence, vas deferens convoluted and testis mass $>0.15 \mathrm{~g}$ females, maximum follicle size $>5.0 \mathrm{~mm}$, oviduct showing development, and ovary mass $>0.08 \mathrm{~g}$, or ovary mass $>0.15 \mathrm{~g}$. According to these criteria, some males begin maturing at around $850 \mathrm{~mm}$ SVL, with the average male maturing at $1000 \mathrm{~mm}$ SVL and all males maturing by $1150 \mathrm{~mm}$ SVL. Females mature over a smaller range of sizes $(840-1120)$; half of the females we examined had matured on attaining a length of $960 \mathrm{~mm}$ SVL (Fig. 2.12). These lengths are substantially greater than those reported for maturing snakes from the snake's native range. It is not known if the size difference is phenotypic or based on lineage differences.

\section{Age}

If the growth rates shown in Fig. 2.11 also characterize initial growth of the Brown Treesnake on Guam, sexual maturation would be reached during a snake's second or third year, as suggested by Fritts and Scott (1985). Investigations to determine the age of captive snakes using bone growth markers in the lingual lamina of the mandible (=prearticular) have been initiated (Collins, 1992; Collins and Rodda, 1994).

In laboratory snakes, growth marks were associated with ecdysis. Laboratory snakes shed an average of 4.3 times per year, an average of once per 85 days. Comparable values on shedding or age relationships are not available for wild $B$. irregularis. Captive $B$. blandingi juveniles shed at 22-78 day intervals (F. Groves, 1973). Although food intake may be higher in captives, shedding is not necessarily more frequent. Carr (1926) reported six sheddings in 11 months for a captive Agkistrodon contortrix that was not fed. Several anecdotes based on snakes tracked with radiotelemetry suggest that Brown Treesnakes become relatively inactive for 8-10 days before ecdysis. 

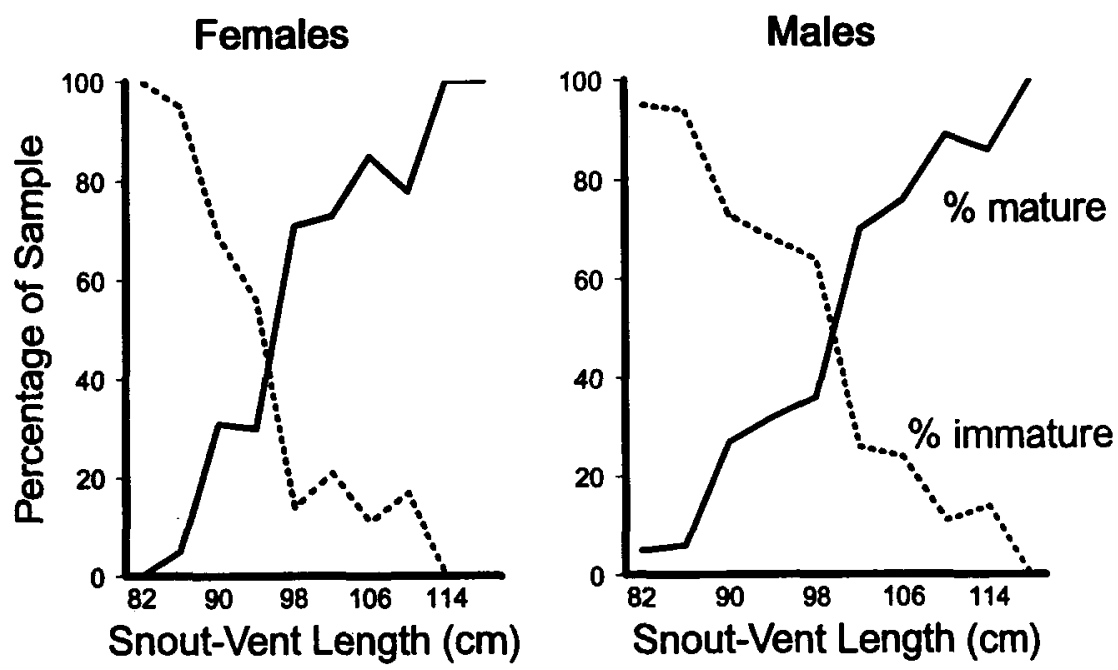

Figure 2.12 Percentages of mature male and female Brown Treesnakes in a sample collected from Guam, 1983-1987. Each $2 \mathrm{~cm}$ SVL size class included about 20 snakes of each sex. These were scored as mature (see text for maturity criteria), maturing, or immature (no evidence of maturation). The mature and immature fractions of the total are shown.

\section{DISEASES AND PARASITES}

A small sample of snakes from Guam was examined for internal parasites by a veterinarian at the National Institutes of Health (D. Nichols, pers. comm., 1992), but no parasites were found. It is not unusual for an extralimital population to lack the intermediate hosts necessary for the transmission of most parasites. Two Brown Treesnakes from New Guinea were cultured for oral parasites (Ross and Marzec, 1984); one of these showed no bacteria and the other exhibited only the ubiquitous Escherichia coli. Neither snake showed any clinical signs of disease. An attempt to induce health impairment in captive snakes using mites failed (Fritts and Scott, 1985). Experiments are under way to test the resistance of Brown Treesnakes to ophidian paramyxovirus (D. Nichols, in litt., 1994).

\section{THE EFFECT OF THE BROWN TREESNAKE ON GUAM}

\section{Species Extirpated}

Since the arrival of the Brown Treesnake on Guam around 1950 (Savidge, 1987; Rodda et al., 1992), most of Guam's indigenous forest vertebrates have been extirpated (Fig. 2.13; Table 2.1). Too few baseline data are available to determine unequivocally the degree to which the snake is responsible for these losses, but several lines of evidence create a very strong case for the snake's role in the 


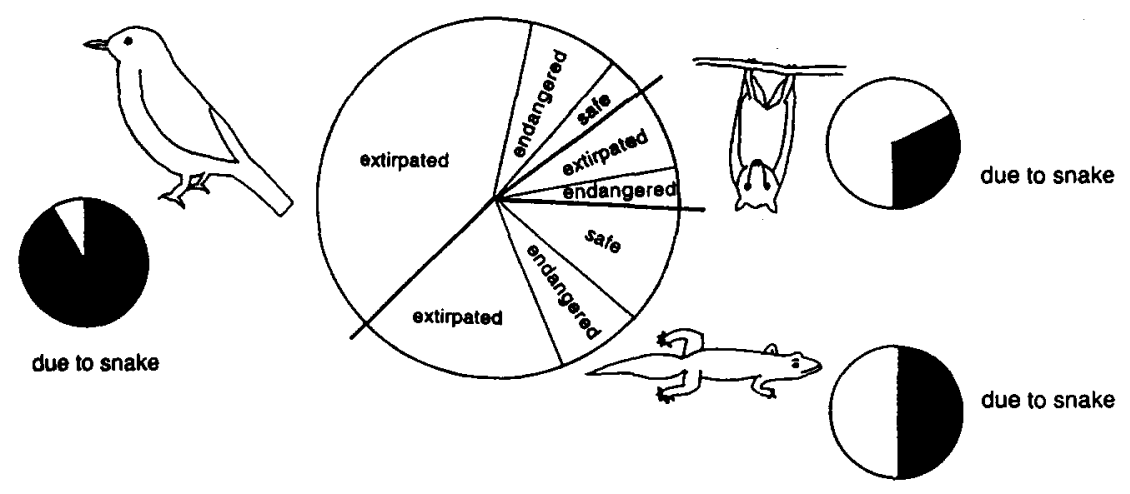

Figure 2.13 Status of Guam's native forest vertebrates (those present in 1950), with estimates of the degree to which decline (black segments) was due to introduction of the Brown Treesnake. The central pie graph represents the vertebrates, and the small pie graphs represent the degree of responsibility for the declines suffered by mammals (upper right), lizards (lower right), and birds (left); heavy lines delineate those major taxa in the central graph.

extirpation of many bird species (Savidge, 1987; Conry, 1988; Engbring and Fritts, 1988) and several lizard species (Rodda and Fritts, 1992b).

There is some evidence that the snake played a role in the decline and disappearance of Guam's native mammals (three species of bats; Wiles, 1987a). Unfortunately, there is no direct information about the two bat species that disappeared before 1980 (Emballonura semicaudata and Pteropus tokudae). In the case of Pteropus mariannus (the one surviving native mammal), poaching may have contributed to the population's decline. Since the late 1980s, however, little poaching has come to light and the bat population has continued to show a failure of recruitment. The primary datum indicating the snake's involvement in this lack of recruitment is the disappearance of young bats only after the age at which they cease accompanying their mothers on all flights. The solitary, nonvolant juveniles are probably easy prey for the snake (Wiles, 1987a).

Evidence that the snake played a role in Guam's extirpations includes the following: (1) the geographic pattern of bird losses mirrored the simultaneous population expansions of the snake; (2) Brown Treesnakes prey on the vertebrate species that declined or disappeared (in most cases the snake is the only predator); (3) there is no evidence of habitat destruction, disease, pesticides, environmental contaminants, or other factors that would account for the losses; (4) all species were affected, including native and nonnative prey species; (5) Brown Treesnake densities on Guam were extraordinarily high at the time of most extirpations (see Rodda et al., this volume, Chap. 17); and (6) no comparable extirpations were observed on nearby islands that lacked the snake (Savidge, 1987). 
Table 2.1 Status of native lerrestrial vertebrates on Guam. Extirpated species (no longer breeding on Guaml ore marked by asterisks.

\begin{tabular}{|c|c|c|}
\hline & $\begin{array}{c}\begin{array}{c}\text { Surviving } \\
\text { species }\end{array} \\
\end{array}$ & $\begin{array}{c}\text { Extirpated by } \\
\text { Brown Treesnake } \\
\end{array}$ \\
\hline \multicolumn{3}{|l|}{ Birds } \\
\hline Pelagic & 0 of 4 & 3 \\
\hline \multicolumn{3}{|l|}{ *Brown Booby (loss not attributable to snake) } \\
\hline \multicolumn{3}{|l|}{ *Fairy Tern } \\
\hline \multirow{2}{*}{\multicolumn{3}{|c|}{$\begin{array}{l}\text { *Brown Noddy } \\
\text { *White-tailed Tropicbird }\end{array}$}} \\
\hline & & \\
\hline Nearshore & 1 of 1 & 0 \\
\hline \multicolumn{3}{|l|}{ Pacific Reef Heron } \\
\hline \multirow{2}{*}{\multicolumn{3}{|c|}{$\begin{array}{l}\text { Wetland/grassland } \\
\text { Moorhen }\end{array}$}} \\
\hline & & \\
\hline \multicolumn{3}{|l|}{ Yellow Bittern } \\
\hline \multirow{2}{*}{\multicolumn{3}{|c|}{$\begin{array}{l}\text { *Mariana Mallard (loss not attributable to snake) } \\
\text { *White-browed Crake (loss not attributable to snake) }\end{array}$}} \\
\hline & & \\
\hline Forest & 3 of 13 & $9 ?$ \\
\hline \multicolumn{3}{|l|}{ Island Swiftlet } \\
\hline \multicolumn{3}{|l|}{ Mariana Crow } \\
\hline \multicolumn{3}{|l|}{ Micronesian Starling } \\
\hline \multicolumn{3}{|l|}{ *Bridled White-eye } \\
\hline \multicolumn{3}{|l|}{ *Guam Flycatcher } \\
\hline \multicolumn{3}{|l|}{ *Guam Rail } \\
\hline \multicolumn{3}{|l|}{${ }^{*}$ Mariana Fruit-Dove } \\
\hline \multicolumn{3}{|l|}{ `Micronesian Honeyeater } \\
\hline \multicolumn{3}{|l|}{ *Micronesian Kingfisher } \\
\hline \multicolumn{3}{|l|}{ * Micronesian Megapode (loss not attributable to snake) } \\
\hline *Nightingale Reed-Warbler & , & \\
\hline \multicolumn{3}{|l|}{ *Rufous Fantail } \\
\hline \multicolumn{3}{|l|}{ "White-throated Ground-Dove } \\
\hline Mammals & 1 of 3 & $?$ \\
\hline \multicolumn{3}{|c|}{$\begin{array}{l}\text { Mariana Fruit Bat } \\
\text { ^Little Mariana Fruit Bat (loss not attributable to snake) } \\
\text { *insectivorous bat (loss not attributable to snake) }\end{array}$} \\
\hline Reptiles & 6 of $10-12$ & $3-5$ \\
\hline \multicolumn{3}{|l|}{ Emoia caeruleocauda } \\
\hline \multicolumn{3}{|l|}{ Hemidactylus frenatus } \\
\hline \multicolumn{3}{|l|}{ Lepidodactylus lugubris } \\
\hline \multicolumn{3}{|l|}{ Lipinia noctua } \\
\hline \multicolumn{3}{|l|}{ Nactus pelagicus } \\
\hline Ramphotyphlops braminus & & \\
\hline${ }^{*}$ Cryptoblepharus poecilopleurus & & \\
\hline${ }^{\star}$ Emoia atrocostata (loss not attributable to snake?) & & \\
\hline *Emoia cyanura (loss not attributable to snake?) & & \\
\hline *Emoia impar (loss not attributable to snake?) & & \\
\hline${ }^{\star}$ Emoia slevini & & \\
\hline *Perochirus ateles & & \\
\hline
\end{tabular}


The pattern of extirpations for all the species followed a size gradient consistent with the snake's dietary habits. Small birds, small mammals, and mediumlarge lizards disappeared first and seem to have been affected most. An exception is the island's one very large lizard, Varanus indicus, which declined after the arrival of the snake, but possibly as a result of poisoning by the introduced toad Bufo marinus (Gressitt, 1952; Dryden, 1965; Uchida, 1967; Covacevich and Archer, 1975). The surviving native species all exhibit some trait that has minimized their vulnerability to the snake; for example, the large size of Pteropus mariannus (Marianas Fruit Bat) and Corvus kubaryi (Marianas Crow); the urban refugia of Aplonis opaca (Micronesian Starling), Lepidodactylus lugubris (Mourning Gecko), and Gehyra mutilata (Mutilating Gecko); the cave ceiling roosts of Aerodramus vanikorensis (Island Swiftlet); and the extremely small size of $L$. lugubris, Lipinia noctua (Moth Skink), and Emoia caeruleocauda (Blue-tailed Skink) (Engbring and Fritts, 1988). Of the surviving native forest-dwelling endotherms-crows, fruit bats, starlings, and swiftlets-fewer than 500 individuals remain, and their longterm population viabilities are in doubt. The small lizards are much more numerous and have better long-term prospects.

\section{Secondary Ecological Impacts}

Along with the disappearance of most of Guam's native vertebrates, ecological processes that are important to the remaining components of the ecosystem have been undermined. For example, flying foxes are important for the pollination (Fujita and Tuttle, 1991) and seed dispersal of tropical trees (Cox et al., 1991). Wiles estimated that flying foxes disperse the seeds of $40 \%$ of the tree species on Guam (Brautigam, 1988). Many of the trees are economically important to island residents (Wiles and Fujita, 1992). One introduced shrub, Lantana camara, has been shown to be declining in apparent response to the loss of native avian seed dispersers (Muniappan, 1988; Denton et al., 1991).

Most of the extirpated species ate insects either primarily or opportunistically. The loss of these insectivores will presumably have an effect on the invertebrate communities of Guam (Pacala and Roughgarden, 1984; Schoener and Spiller, 1987), but to date that effect has not been investigated. An increase in the abundance of insects, especially of frugivorous species able to feed on fruit formerly consumed by the extirpated vertebrate frugivores, could have a major economic impact on agriculture on Guam, and this possibility has not yet been evaluated either. Spiders seem unusually abundant on Guam; perhaps they are the beneficiaries of increased insect prey and reduced predation by birds and lizards.

In addition to the loss of native forest birds (Fig. 2.13), sea birds have not nested successfully on Guam since 1980 (with rare exceptions). In the outer islands, Micronesians rely on seabirds for locating schools of pelagic fish and finding distant islands. 


\section{Other Adverse Effects of the Brown Treesnoke's Presence on Guam}

The snake is a formidable predator on neonatal domestic mammals and fowl (Fritts and McCoid, 1991). Eating fruit bats is an important part of rituals and celebrations conducted by the indigenous peoples of the Mariana Islands. The decline of bat populations on Guam has limited this cultural practice, and the unmet demand for bats on Guam has stimulated excessive bat harvests in other areas of the Pacific (Wilson and Graham, 1992).

The numerous power outages caused by the snake are discussed by Fritts and Chiszar in Chapter 4 of this volume. Frequent power outages are an impediment to Guam's rapidly expanding tourist trade. The prospect that tourists may encounter large venomous snakes that strike repeatedly when cornered is a deterrent to Guam's tourism industry as well.

The multiple adverse effects of the snake on Guam are a grave concern to other Pacific islanders in areas presently devoid of Brown Treesnakes. The snake has been found on several Pacific and Indian Ocean islands with transportation links to Guam (Fritts, 1987; McCoid and Stinson, 1991; Fritts et al., this volume, Chap. 14). Saipan (Gomez, 1992) and Oahu (Anon., 1991) seem to be most at risk (Fritts et al., this volume, Chap. 14). Saipan experienced almost one snake sighting per month in the period 1990-1993. As yet, no established extralimital population outside Guam has been documented.

Efforts have been initiated to reduce the number of snakes in cargo and vessels traveling from Guam (Campbell et al., this volume, Chap. 35 ). These control activities unavoidably complicate exportation and raise costs for both civilian and military actions based in Guam. Preventive measures result in higher costs to consumers. The Brown Treesnake affects all military and business activities on Guam that require electrical power or depend on tourist visitation, all farm practices that use domestic animals or raise crops sensitive to pest insects, all activities that rely on or benefit from natural vertebrate communities (Fritts, 1988), and everyone's personal safety or tranquillity in the home and out-of-doors. It is difficult to identify another introduced species anywhere on Earth that has had such a comprehensive impact.

\section{Why Such an Exireme Effect?}

Four classes of factors have been suggested as being responsible for the magnitude of the Brown Treesnake's impacts: (1) the snake is an exceptional predator, (2) Guam had an exceptionally vulnerable fauna, (3) Guam's food web had a vulnerable structure, and (4) the new predator and its prey on Guam had not coevolved.

Is the Brown Treesnake an exceptional predator? Unlike more familiar pest species, such as the rat, snakes do not need to eat regularly (Habu can survive several years without food, Nakamoto et al., 1981). This means that a snake can 
hide in cargo and be transported for weeks or months without starving or exposing itself to discovery by emerging to feed (McCoid et al., 1994). The Brown Treesnake can subsist on virtually any small or medium-sized vertebrate prey, and it can find suitable food in almost any tropical environment.

The Brown Treesnake is an extraordinary climber, so few areas of the natural environment are inaccessible to it (Fritts and Chiszar, this volume, Chap. 4). The snake is also well adapted to disturbed habitats. This implies that it can be found in close proximity to humans and cargo.

The Brown Treesnake has no eye shine; it is nocturnal, cryptic, secretive, and takes advantage of its extremely thin body to conceal itself in spaces that are unsuitable for most animals (we once found 11 snakes, 2 of which were much larger than $1.2 \mathrm{~m} \mathrm{SVL}$, concealed within a short piece of 6-cm-diameter pipe). The snake is highly successful at avoiding detection. These traits all contribute to the undetected transport of the snake to new localities. Note, however, that these traits are common among snakes and nearly universal among species of the genus Boiga. Had B. irregularis not been introduced to Guam, B. angulata, B. cynodon, or any nocturnal arboreal snake might have been (Greene, 1989).

Was Guam an especially vulnerable environment? The climate of Guam is suitable for most of the world's animals. There are no periods of severe cold or dryness to limit dispersal of an introduced species. Before the snake arrived, Guam had high densities of many prey species (Rodda et al, this volume, Chap. 17). Furthermore, the Brown Treesnake did not have to compete with other predators for food. Being a remote island, Guam had endemic species vulnerable to extinction because they occurred in a limited area. The geographic limits of Guam are so confining that a population would not have time to recover from a predator irruption on one part of the island before the effects of the irruption spread throughout the island. This would not have been the case on a large island such as New Britain. The distance from Guam to the closest islands also ensured that most prey species would be unable to disperse from Guam to snake-free habitats. These factors all contributed to the severity of the Brown Treesnake's effect on Guam's fauna, but they are not unique to Guam. These vulnerabilities are shared by most oceanic islands and many other areas of discontinuous habitat.

Guam received a great deal of post-World War II traffic related to disposal of military surplus, and this provided a dispersal opportunity for the snake and other vertebrate species; all populations of introduced species increased, and other introduced species formed an expanding prey base. The widespread destruction on Guam during the war and revegetation afterward formed large areas of introduced secondary growth, a habitat the snake was able to exploit, and may have contributed to the expansion of other introduced species such as the Musk Shrew (Suncus murinus) and the skink Carlia cf. fusca.

Was the Guam food web especially vulnerable to disruption by the Brown Treesnake? Because the snake is a dietary generalist, its numbers did not decline in response to the extirpation of avian prey (Pimm, 1987; Savidge, 1987). When 
birds became scarce, large snakes switched to lizards (Fig. 2.9). Had the snake been specialized to feed on birds, it probably would have extirpated fewer bird species and its population would have declined to lower levels.

Was the lack of coevolution between predator and prey the key missing ingredient on Guam? Guam's native birds lacked the defenses needed to protect themselves and their progeny from snake predation. This trait is shared by many island species that show "island tameness." Consistent with this idea is the observation that 200 of 217 recent bird extinctions have occurred on islands (Brockie et al., 1988). We believe the lack of coevolved predator defenses is the central factor responsible for Guam's avifauna collapse. Whenever a species is introduced, coevolution will be lacking and indigenous species will be threatened with extirpation. This phenomenon is not unique to either the Brown Treesnake or Guam.

\section{Why Was the Response of Wild life Managers Ineffective?}

The Brown Treesnake lived on Guam for about 35 years before its presence was associated with the demise of the island's native birds (Engbring, 1983; Jenkins, 1983; Engbring and Ramsey, 1984; Savidge, 1984; Marshall, 1985). Until 1985, efforts to discover the reasons for the disappearance of Guam's birds were limited to those by ornithologists, who used the misleading extinction models that had been developed for Hawaii. The insights of herpetologists were not available.

Nor was the physical absence of herpetologists the only missing ingredient. Herpetology was and is almost exclusively a pure science focused on continental ecosystems near major universities. Unfortunately, the continental viewpoint can be misleading. Smith and Kohler (1978) reviewed continental introductions of reptiles and concluded they were benign. These authors made a rare foray into the realm of applied herpetology, but this is not a spécialty for which academic herpetologists are rewarded. Applied research in herpetology is not a pathway to tenure, publications, or grant money. There are no accredited training programs for applied herpetologists, and to our knowledge there are no academic courses in applied herpetology.

The factors described above all played a role in limiting the effectiveness of wildlife managers' responses to the disappearance of Guam's wildlife, although the biggest problem was simply that there was and is no known way to eradicate a well-established snake population. With the technology and information available today, prevention is the only viable tool for avoiding extirpations caused by introduced reptiles.

\section{ACKNOWLEDGMENTS}

We thank the U.S. Departments of the Interior and Defense for support, and Cynthia Melcher, Renée Rondeau, Dave Worthington, and Steve Gotte for suggesting improvements to the manuscript. 


\section{Roddo, Fritts, McCoid, \& Compbell}

\section{LITERATURE CITED}

ANDrews, R. M. 1982. Patterns of growth in reptiles. In C. Gans and F. H. Pough, eds., Biology of the Reptilia, vol. 13, pp. 273-320. London: Academic Press.

ANoN. 1991. Recommended Protocol for Transport to and Transit through Hawaii of Live Brown Tree Snakes (Boiga irregularis). Honolulu: Pacific Basin Development Council.

Armstrong, D. P., AND G. H. Pyke. 1991. Seasonal patterns of reproduction in heathland honeyeaters are not responses to changing nectar availability. Auk 108:99-107.

BARACH, J. P. 1952. Some observations on the Mangrove Snake in captivity. Herpetologica 8:102-103.

Bosch, H. A. J. IN DEN. 1985. Snakes of Sulawesi: Checklist, key, additional biogeographical remarks. Zool. Verh. (Leiden) 217:3-50.

Boulznger, G. H. 1896. Catalogue of the Snakes in the British Museum (Natural History), vol. 3. London: Taylor \& Francis.

Brautigam, A. 1988. Flying foxes in danger. IUCN SSC Species 11:11-12.

BROCKIE, R. E., L. L. LOOPE, M. B. USHER, AND O. HAMANN. 1988. Biological invasions of island nature preserves. Biol. Conserv. 44:9-36.

BURGER, W. L. 1975. A case of mild envenomation by the Mangrove Snake, Boiga dendrophila. Snake 6:99-100.

CARR, W. H. 1926. The fasting of a Copperhead. Copeia 150:104.

Chiszar, D. A. 1990. Behavior of the Brown Tree Snake, Boiga irregularis. A study in applied comparative psychology. In D. Dewsbury, ed., Contemporary Issues in Comparative Psychology, pp. 101-123. Sunderland, Mass.: Sinauer.

Chiszar, D., D. Carrillo, P. Rand, J. Chiszar, and H. M. Smith. 1985. Nocturnal activity in captive Brown Tree Snakes Boiga irregularis. Bull. Md. Herpetol. Soc. 21:115-118.

Chiszar, D., ANd K. Kandibr. 1986. Adjustment of Brown Tree Snakes (Boiga irregularis) to a reversed light cycle. Bull. Md. Herpetol. Soc. 22:171-174.

Chiszar, D., C. W. RAdchiffe, H. M. SMith, AND P. LANger. 1991. Strike-induced chemosensory searching: Do rattlesnakes make one decision or two? Bull. Md. Herpetol. Soc. 27:90-94.

Cogger, H. G. 1992. Reptiles and Amphibians of Australia, 5th ed. Ithaca: Cornell Univ. Press.

Cogger, H. G., aND H. Heatwole. 1981. Australian reptiles: Origins, biogeography, distribution patterns and island evolution. In A. Keast, ed., Ecological Biogeography of Australia, pp. 1333-1373. The Hague: W. Junk.

Collins, E. P. O. 1992. Skeletochronology as a method of estimating age in the Brown Tree Snake (Boiga irregularis). M.S. thesis, Univ. of Arizona, Tucson.

Collins, E. P. O., AND G. H. RoDDA. 1994. Bone layers associated with ecdysis in laboratory-reared Boiga irregularis (Colubridae). J. Herpetol. 28:378-381.

ConRY, P. J. 1988. High nest predation by Brown Tree Snakes on Guam. Condor 90:478-482. 
Covaczvich, J., And M. Archrr. 1975. The distribution of the Cane Toad, Bufo marinus, in Australia and its effects on indigenous vertebrates. Mem. Qd. Mus. 17:305-310.

Covacevich, J., AND C. Limpus. 1973. Two large winter aggregations of three species of tree-climbing snakes in south-eastern Queensland. Herpetofauna 6:16-21.

Cox, M. J. 1991. The Snakes of Thailand and Their Husbandry. Malabar, Fla.: Krieger.

Cox, P. A., T. Elmovist, E. D. Pierson, And W. E. Rainey. 1991. Flying foxes as strong interactors in South Pacific island ecosystems: A conservation hypothesis. Conserv. Biol. 5:448-454.

Denton, G. R. W., R. Muniappan, And M. Marutani. 1991. The distribution and biological control of Lantana camara in Micronesia. Micronesica Suppl. 3:71-81.

DrYDEN, G. L. 1965. The food and feeding habits of Varanus indicus on Guam. Micronesica 2:72-76.

Dubliman, W. E. 1990. Herpetofaunas in Neotropical rainforests: Comparative composition, history, and resource use. In A. H. Gentry, ed., Four Neotropical Rainforests, pp. 455-505. New Haven: Yale Univ. Press.

Duméril, A. M. C., G. Bibron, ANd A. H. A. Duméril. 1854. Erpétologie Générale ou Histoire Naturelle Complète des Reptiles, vol. 7, pt. 2, Comprenant l'Histoire des Serpents Venimeux, pp. 781-1536. Paris: Librairie Encyclopédique de Roret.

Ermann, H. 1992. Encyclopedia of Australian Reptiles. Pymble, N.S.W., Australia: Collins, Angus \& Robertson.

ELDREDGE, L. G. 1983. Summary of environmental and fishing information on Guam and the Commonwealth of the Northern Mariana Islands: Historical background, description of the islands, and review of the climate, oceanography, and submarine topography. U.S. Dept. of Commerce, National Oceanic and Atmospheric Administration, National Marine Fisheries Service, Southwest Fisheries Center.

ENGBRING, J. 1983. Forest birds of Guam in critical danger. U.S. Fish Wildl. Serv., Endang. Species Tech. Bull. 8:6-8.

EngBring, J., AND T. H. Fritts. 1988. Demise of an insular avifauna: The Brown Tree Snake on Guam. Trans. West. Sect. Wildl. Soc. 24:31-37.

ENGBRING, J., AND F. L. RAMSEY. 1984. Distribution and abundance of the forest birds of Guam: Results of a 1981 survey. U.S. Fish Wildl. Serv., FWS/OBS-84/20.

ERnst, C. H., AND R. W. BARbour. 1989. Snakes of Eastern North America. Fairfax, Va.: George Mason Univ. Press.

Fitch, H. S. 1960. Autecology of the Copperhead. Univ. Kans. Publ. Mus. Nat. Hist. 13:85-288.

-1982. Reproductive cycles in tropical reptiles. Occas. Pap. Mus. Nat. Hist. Univ. Kans. 96:1-53.

- 1987. Collecting and life-history techniques. In R. A. Seigel, J. T. Collins, and S. S. Novak, eds., Snakes: Ecology and Evolutionary Biology, pp. 143-164. New York: Macmillan.

Fritrs, T. H. 1987. Movements of snakes via cargo in the Pacific region. 'Elepaio 47:17-18.

-1988. The Brown Tree Snake, Boiga irregularis, a Threat to Pacific Islands. U.S. Fish Wildl. Serv., Biol. Rep. 88(31). 
Fritts, T. H., AND M. J. McCoId. 1991. Predation by the Brown Tree Snake on poultry and other domesticated animals in Guam. Snake 23:75-80.

FritTs, T. H., AND N. J. ScotT, Jr. 1985. The Brown Tree Snake on Guam: Studies of its ecology, control, and threats to other islands. Final report. Portland, Ore.: U.S. Fish and Wildlife Service.

FritTs, T. H., N. J. ScotT Jr., AND J. A. SAvidge. 1987. Activity of the arboreal Brown Tree Snake (Boiga irregularis) on Guam as determined by electrical power outages. Snake 19:51-58.

FujitA, M. S., AND M. D. Tutrle. 1991. Flying foxes (Chiroptera: Pteropodidae): Threatened animals of key ecological and economic importance. Conserv. Biol. 5:455-463.

GiLlinghaM, J. C. 1987. Social behavior. In R. A. Seigel, J. T. Collins, and S. S. Novak, eds., Snakes: Ecology and Evolutionary Biology, pp. 184-209. New York: Macmillan.

Gomez, D. M. 1992. Division of Fish and Wildlife Brown Tree Snake control/interdiction 1992 project goals. Report on file with CNMI Division of Fish and Wildlife, Saipan.

Gow, G. F. 1976. Snakes of Australia. London: Angus \& Robertson.

GreEne, H. W. 1979. Behavioral convergence in the defensive displays of snakes. Experientia 35:747-748.

-1989. Ecological, evolutionary, and conservation implications of feeding biology in Old World cat snakes, genus Boiga (Colubridae). Proc. Calif. Acad. Sci. 46:193-207.

GressitT, J. L. 1952. Description of Kayangel Atoll, Palau Islands. Atoll Res. Bull. $14: 1-6$.

Groves, F. 1973. Reproduction and venom in Blanding's Tree Snake. Int. Zoo Yearb. 13:106-108.

Groves, J. D. 1973. Delayed fertilization in the snake Boiga dendrophila. Herpetologica 29:20-22.

-1974. Reproduction in the Mangrove Snake Boiga dendrophila at Baltimore Zoo. Int. Zoo Yearb. 14:82.

GUYBR, C., AND M. A. DonNBLlY. 1990. Length-mass relationships among an assemblage of tropical snakes in Costa Rica. J. Trop. Ecol. 6:65-76.

HaInes, T. P. 1940. Delayed fertilization in Leptodeira annulata polysticta. Copeia 1940:116-118.

Henderson, R. W. 1993. Foraging and diet in West Indian Corallus enydris (Serpentes: Boidae). J. Herpetol. 27:24-28.

Henderson, R. W., J. R. Dixon, ANd P. Soini. 1978. On the seasonal incidence of tropical snakes. Milwaukee Public Mus. Contrib. Biol. Geol. 17:1-15.

HOSER, R. T. 1980. Further records of aggregations of various species of Australian snakes. Herpetofauna 12:16-22.

Howard, C. J. 1987. Boiga dendrophila, the Mangrove Snake. In K. R. G. Welch, ed., Handbook on the Maintenance of Reptiles in Captivity, pp. 52-54. Malabar, Fla.: Krieger. 
HowARD, R. D. 1984. Alternative behaviors of young male bullfrogs. Am. Zool. 24:397-406.

Jenkins, J. M. 1983. The native forest birds of Guam. AOU Ornithol Monogr. 31 .

Johnson, C. R. 1975a. Thermoregulation in the Papuan-New Guinean boid and colubrid snakes, Candoia carinata, Candoia aspera, and Boiga irregularis. Zool. J. Linn. Soc. 56:283-290.

1975b. Defensive display behaviour in some Australian and Papuan-New Guinean pygopodid lizard, boid, colubrid, and elapid snakes. Zool. J. Linn. Soc. 56:265-282.

JONES, T. S. 1961. Notes on bat-eating snakes. Nigerian Field 26:69-70.

KaUfman, G. A., AND J. W. GibBons. 1975. Weight-length relationships in thirteen species of snakes in the southeastern United States. Herpetologica 31:31-37.

KINGHORN, J. R. 1964. Snakes of Australia. Sydney: Angus \& Robertson.

KıAUBer, L. M. 1972. Rattlesnakes, 2nd ed., 2 vols. Berkeley: Univ. of California Press.

Kopstein, F. 1938. Ein Beitrag zur Eierkunde und zur Fortpflanzung der Malaiischen Reptilien. Bull. Raffles Mus. 14:81-167.

Leviton, A. E. 1968. Contributions to a review of Philippine snakes, XI. The snakes of the genus Boiga. Philippine J. Sci. 97:291-314.

Lillywhite, H. B. 1987. Circulatory adaptations of snakes to gravity. Am. Zool. 27:81-95.

Lillywhite, H. B., AND R. W. Henderson. 1993. Behavioral and functional ecology of arboreal snakes. In R. A. Seigel and J. T. Collins, eds., Snakes: Ecology and Behavior, pp. 1-48. New York: McGraw-Hill.

LUTTERSChMIDT, W. I., AND L. A. RAYBURN. 1993. Observations of feeding behavior in Thamnophis marcianus after surgical procedures. J. Herpetol. 27:95-96.

LUTterschmidT, W. I., AND H. K. REINERT. 1990. The effect of ingested transmitters upon the temperature preference of the Northern Water Snake, Nerodia s. sipedon. Herpetologica 46:39-42.

Macartney, J. M., P. T. Gregory, and K. W. LARsen. 1988. A tabular survey of data on movements and home ranges of snakes. J. Herpetol. 22:61-73.

Marshall, J. T. 1985. Special conservation review: Guam: A problem in avian conservation. Wilson Bull. 97:259-262.

McCoID, M. J. 1994. Boiga irregularis (Brown Tree Snake) reproduction. Herpetol. Rev. 25:69-70.

McCoid, M. J., T. H. Fritts, and E. W. Campbell III. 1994. A Brown Tree Snake (Colubridae: Boiga irregularis) sighting in Texas. Tex. J. Sci. 46:365-368.

McCoID, M. J., AND D. W. Stinson. 1991. Recent snake sightings in the Mariana Islands. 'Elepaio 51:36-37.

McCoy, M. 1980. Reptiles of the Solomon Islands. Wau, Papua New Guinea: Wau Ecology Institute.

McDowell, S. B. 1984. Results of the Archbold Expeditions No. 112. The snakes of the Huon Peninsula, Papua New Guinea. Am. Mus. Novit. 2775:1-28.

Mengden, G. A., AND H. G. Coggrr. n.d. Identification Guide to the Snakes of Madang Province, Papua New Guinea. Privately printed. 
Minton, S. A., AND W. A. Dunson. 1978. Observations on the Palawan Mangrove Snake, Boiga dendrophila multicincta (Reptilia, Serpentes, Colubridae). J. Herpetol. 12:107-108.

MUNIAPPAN, R. 1988. Biological control of the weed Lantana camara in Guam. J. Plant Prot. Trop. 5:99-101.

Nakamoto, E., H. Fuxushima, ANd Y. Sawai. 1981. Longevity of Habu (Trimeresurus flavoviridis) maintained in a hungry condition [in Japanese with English summary]. Snake 13:61-62.

Nishimura, M., AND T. Kamura. 1989. Sizes of female Habu, Trimeresurus flavoviridis, and their eggs and hatchlings 6 [in Japanese]. In C. Yoshida, ed., Reports of Ecological Researches to Diminish Bites of Habu (Trimeresurus flavoviridis) in Okinawa Prefecture, vol. 12, pp. 69-71. Ozato, Okinawa, Japan: Dept. of Habu, Okinawa Prefectural Inst. of Public Health.

Nishimura, M., H. Shiroma, T. Kamura, Y. Kochi, K. Takahira, and A. Hiraiwa. 1988. Results of trapping Habu (Trimeresurus flavoviridis)—mainly those in 1987 [in Japanese]. In C. Yoshida, ed., Reports of Ecological Researches to Diminish Bites of Habu (Trimeresurus flavoviridis) in Okinawa Prefecture, vol. 11, pp. 45-57. Ozato, Okinawa, Japan: Habu Study Sect., Okinawa Prefectural Inst. of Health and Env.

Овsт, F. J., K. Richter, AND U. JACOB. 1988. The Completely Illustrated Atlas of Reptiles and Amphibians for the Terrarium. Neptune City, N.J.: T.F.H. Publications.

O'shes, M. 1990. The reptiles of Madang Province. Christensen Res. Inst. Field Rep. 105.

PACAla, S., AND J. Roughgarden. 1984. Control of arthropod abundance by Anolis lizards on St. Eustatius (Neth. Antilles). Oecologica 64:160-162.

PAlmer, W. M., AND A. L. Braswell. 1976. Communal egg laying and hatchlings of the Rough Green Snake, Opheodrys aestivus (Linnaeus) (Reptilia, Serpentes, Colubridae). J. Herpetol. 10:257-259.

PArker, F. 1982. The snakes of the western province. Wildl. Papua New Guinea 82:32-33.

Pendleton, R. C. 1947. A snake "den" tree on Guadalcanal Islańd. Herpetologica 3:189-190.

Pimm, S. L. 1987. The snake that ate Guam. Trends Ecol. Evol. 2:293-295.

Plummzr, M. V. 1985. Demography of green snakes (Opheodrys aestivus). Herpetologica 41:373-381.

RodDA, G. H. 1989. Progress report on visual censusing techniques. Report on file with Arizona Cooperative Fish and Wildlife Research Unit, Tucson, Ariz.

- 1991. Fence climbing by the arboreal snake Boiga irregularis. Snake 23:101-103.

_ 1992 . Foraging behaviour of the Brown Tree Snake, Boiga irregularis. Herpetol. J. 2:110-114.

RodDA, G. H., AND T. H. Fritrs. 1992a. Sampling techniques for an arboreal snake, Boiga irregularis. Micronesica 25:23-40.

- 1992b. The impact of the introduction of the Brown Tree Snake, Boiga irregularis, on Guam's lizards. J. Herpetol. 26:166-174.

RODDA, G. H., T. H. FrITTS, AND P. J. ConRY. 1992. Origin and population growth of the Brown Tree Snake, Boiga irregularis, on Guam. Pac. Sci. 46:46-57. 
Rodda, G. H., T. H. Fritts, AND J. D. ReIChel. 1991. The distributional patterns of reptiles and amphibians in the Mariana Islands. Micronesica 24:195-210.

Rosen, P. C. 1991. Comparative ecology and life history of the racer (Coluber constrictor) in Michigan. Copeia 1991:897-909.

RoseveAR, D. R. 1965. The Bats of West Africa. London: British Museum (Natural History).

Ross, R. A., AND G. Marzec. 1984. The Bacterial Diseases of Reptiles: Their Epidemiology, Control, Diagnosis and Treatment. Stanford, Calif.: Institute for Herpetology Research.

Saint Girons, H. 1975. Sperm survival and transport in the female genital tract of reptiles. In E. S. E. Hafez and C. G. Thibault, eds., The Biology of Spermatozoa, pp. 105-113. New York: S. Karger.

SARAI, A., M. HoNma, AND Y. SAWAi. 1984. Study of the toxicity of venoms extracted from Duvernoy's gland of certain Asian colubrid snakes. Snake 16:16-20.

Santana-Bendix, M. A. n.d. Movements and activity patterns of the Brown Tree Snake (Boiga irregularis) on the island of Guam. Report on file with Arizona Cooperative Fish and Wildlife Research Unit, Tucson, Ariz.

SAvidGE, J. A. 1984. Guam: Paradise lost for wildlife. Biol. Conserv. 30:305-317.

- 1986. The role of disease and predation in the decline of Guam's avifauna. Ph.D. diss., Univ. Illinois, Urbana-Champaign.

- 1987. Extinction of an island forest avifauna by an introduced snake. Ecology 68:660-668.

- 1988. Food habits of Boiga irregularis, an introduced predator on Guam. J. Herpetol. 22:275-282.

Schoener, T. W., AND D. A. SpILler. 1987. Effects of lizards on spider populations: Manipulative reconstruction of a natural experiment. Science 236:949-952.

SECOR, S. M. 1992. A preliminary analysis of the movement and home range size of the Sidewinder, Crotalus cerastes. In J. A. Campbell and E. D. Brodie Jr., eds., Biology of the Pitvipers, pp. 389-393. Tyler, Tex.: Selva.

SEIGEL, R. A., AND N. B. Ford. 1987. Reproductive ecology. In R. A. Seigel, J. T. Collins, and S. S. Novak, eds., Snakes: Ecology and Evolutionary Biology, pp. 210-252. New York: Macmillan.

SHINE, R. 1991. Strangers in a strange land: Ecology of Australian colubrid snakes. Copeia 1991:120-131.

SMITH, H. M., AND A. J. KoHLER. 1978. A survey of herpetological introductions in the United States and Canada. Trans. Kans. Acad. Sci. 80:1-24.

Stanley, D. 1985. Micronesia Handbook. Chico, Calif.: Moon.

StorR, G. M., L. A. SMith, AND R. E. Johnstone. 1986. Snakes of Western Australia. Perth: Western Australia Museum.

SWEENEY, R. C. H. 1971. Snakes of Nyasaland. Amsterdam: A. Asher.

UCHIDA, T. 1967. Observations on the monitor lizard, Varanus indicus (Daudin), as a rat control agent on Ifaluk, Western Caroline Islands. Micronesica 3:17-18.

WeLCH, K. R. G. 1988. Snakes of the Orient: A Checklist. Malabar, Fla.: Krieger.

WILES, G. J. 1986. Preliminary results of a radio-tracking study of Brown Tree Snakes on Guam. In R. D. Anderson, P. J. Conry, and M. E. Molina, eds., Annual Report, 
Fiscal Year 1985, Guam Aquatic and Wildlife Resources Division, pp. 127-135. Mangilao, Guam: Dept. of Agriculture.

- 1987a. Current research and future management of Marianas Fruit Bats (Chiroptera:Pteropodidae) on Guam. Aust. Mammal. 10:93-95.

- 1987b. Movements, home range and activity patterns of Brown Tree Snakes. In R. D. Anderson and P. J. Conry, eds., Annual Report, Fiscal Year 1986, Guam Aquatic and Wildlife Resources Division, pp. 138-140. Mangilao, Guam: Dept. of Agriculture.

. 1988. Movements, home range and activity patterns of the Brown Tree Snake. In G. R. Grimm and L. L. Mariano, eds., Annual Report, Fiscal Year 1987, Guam Aquatic and Wildlife Resources Division, pp. 139-142. Mangilao, Guam: Dept. of Agriculture.

Wiles, G. J., AND M. S. FujITA. 1992. Food plants and economic importance of flying foxes on Pacific Islands. In D. E. Wilson and G. L. Graham, eds., Pacific Island Flying Foxes: Proceedings of an International Conservation Conference, pp. 24-35. U.S. Fish Wildl. Serv. Biol. Rep. 90(23).

Wilson, D. E., AND G. L. Graham, eds. 1992. Pacific Island Flying Foxes: Proceedings of an International Conservation Conference. U.S. Fish Wildl. Serv., Biol. Rep. 90(23).

WoodWARD, S. F. 1960. A bat-eating snake. Nigerian Field 25:172-174.

WORRELL, E. 1963. Reptiles of Australia. Sydney: Angus \& Robertson.

Zwinenberg, A. J. 1978. Die Braune Nachtbaumnatter Boiga irregularis. Aquar.

Terrar. Z. 31:177-179. 